\title{
Synthesis and in vitro evaluation of piperazinyl-ureido sulfamates as steroid sulfatase inhibitors
}

Davide Moi, ${ }^{\text {at }}$ Paul A. Foster, ${ }^{\text {b, c }}{ }^{\dagger}$ Lucy G. Rimmer, ${ }^{b}$ Alisha Jaffri, ${ }^{b}$ Alessandro Deplano, ${ }^{\text {a }}$ Gianfranco Balboni, ${ }^{a}$ Valentina Onnis, ${ }^{\text {a* }}$ and Barry V. L. Potter ${ }^{d *}$

${ }^{a}$ Department of Life and Environmental Sciences, Unit of Pharmaceutical, Pharmacological and Nutraceutical Sciences, University of Cagliari, via Ospedale 72, Cagliari I-09124, Italy

${ }^{\mathrm{b}}$ Institute of Metabolism and Systems Research, University of Birmingham, $2^{\text {nd }}$ Floor IBR Tower, Birmingham, B15 2TT, UK

${ }^{\text {CC}}$ Centre for Endocrinology, Diabetes and Metabolism, Birmingham Health Partners, Birmingham, B15 2TH, UK ${ }^{\mathrm{d}}$ Medicinal Chemistry \& Drug Discovery, Department of Pharmacology, University of Oxford, Mansfield Road, Oxford, OX1 3QT, UK

*To whom correspondence should be addressed. E-mail: vonnis@unica.it; barry.potter@pharm.ox.ac.uk

${ }^{\dagger}$ These authors contributed equally to the present paper

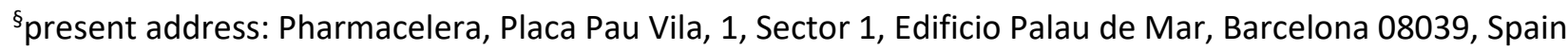

\section{Highlights}

* Piperazinyl-ureido sulfamates were designed and synthesised.

* Synthesised compounds were assayed in vitro as steroid sulfatase (STS) inhibitors.

* Synthesised compound inhibited STS with micromolar to low nanomolar potency.

* Selected STS inhibitors are membrane permeant in a JEG-3 human placenta choriocarcinoma cell line.

* The sulfamates 19 and 20 had STS IC ${ }_{50}$ values of 5.1 and $8.8 \mathrm{nM}$ respectively.

\section{Keywords}

Piperazines, Ureido compounds, Sulfamates, Pyrimidines, Steroid sulfatase, Enzyme inhibition.

\section{Graphical abstract}
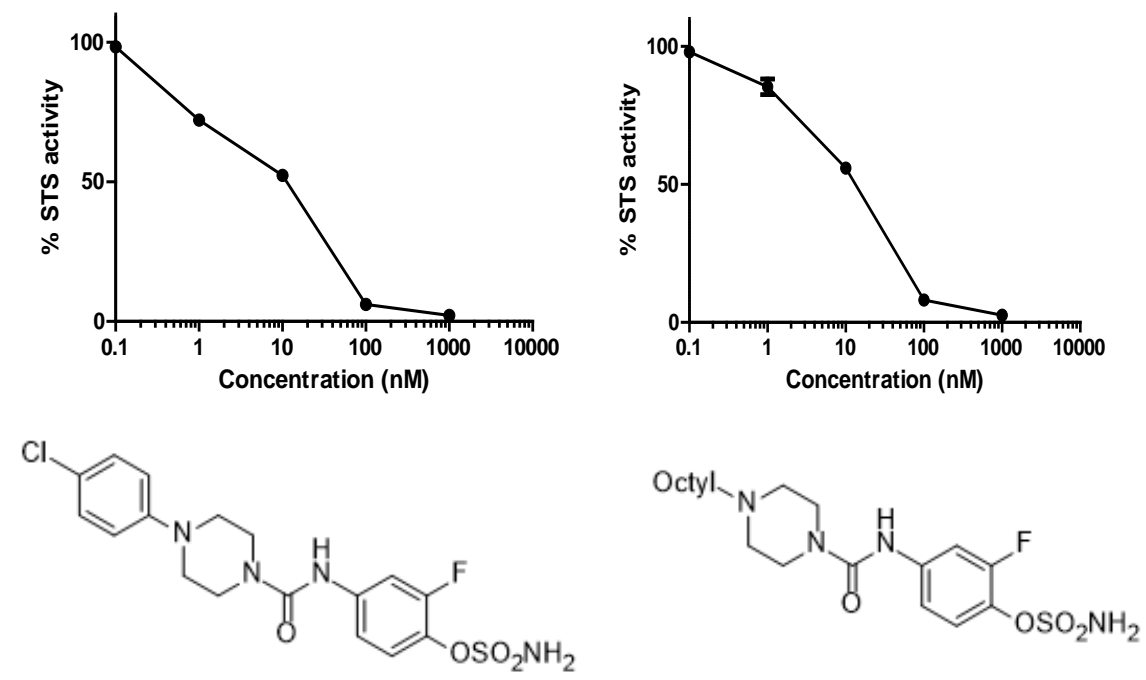

Residual STS \% activity $7.1 \pm 0.7$ STS IC $50.1 \mathrm{nM}$ 


\begin{abstract}
Two new piperazinyl-ureido single ring aryl sulfamate-based inhibitor series were designed against the emerging oncology drug target steroid sulfatase (STS), for which there are existing potent steroidal and nonsteroidal agents in clinical trials. 4-(Piperazinocarbonyl)aminosulfamates (5-31) were obtained by reacting 4-hydroxyarylamines with phenylchloroformate, subsequent sulfamoylation of the resulting hydroxyarylcarbamates and coupling of the product with 1-substituted piperazines. Pyrimidinylpiperazinourea sulfamates (35-42) were synthesized by pyrimidine ring closure of 4-Boc-piperazine-1carboxamidine with 3-(dimethylamino)propenones, deprotection and coupling with the sulfamoylated building block. Target ureidosulfamates 5-31 and 35-42 were evaluated both as STS inhibitors in vitro using a lysate of JEG-3 human placenta choriocarcinoma cell line and in a whole cell assay. SAR conclusions were drawn from both series. In the series 35-42 the best inhibitory activity is related to the presence of a benzofuryl on the pyrimidine ring. In the series 5-31 the best inhibitory activity was shown by the ureas bearing 4-chlorophenyl, 3,4-dichlorophenyl groups or aliphatic chains at the piperazino 4-nitrogen displaying $I_{50}$ in the 33-94 nanomolar concentration range. Final optimization to the low nanomolar level was achieved through substitution of the arylsulfamate ring with halogens. Four halogenated arylsulfamates of high potency were achieved and two of these 19 and 20 had IC $5_{50}$ values of 5.1 and $8.8 \mathrm{nM}$ respectively and are attractive for potential in vivo evaluation and further development. We demonstrate the optimization of this new series to low nanomolar potency, employing fluorine substitution, providing potent membrane permeant inhibitors with further development potential indicating piperazinyl-ureido aryl sulfamate derivatives as an attractive new class of STS inhibitors.
\end{abstract}

\title{
1. Introduction
}

Estrogen signalling is a well-established target for breast cancer drug discovery [1] with clinical drugs such as Tamoxifen, acting at the estradiol receptor, and aromatase inhibitors blocking biosynthetic conversion of androgens to estrogens, the main standards of clinical care. More recently, a new drug target steroid sulfatase (STS) has become an emerging new therapeutic modality with its inhibition showing clinical benefit and the first clinical trial data published in 2006 [2]. STS is widely distributed throughout the body and is involved in numerous physiological and pathological conditions [3] including hormone-dependent cancers [4], Iysosomal storage disorders, developmental abnormalities, and bacterial pathogenesis [5]. Primarily, STS catalyzes the desulfation of biologically inactive steroid sulfates into their bioactive forms. It can work in an intracrine fashion, playing a crucial role in the in situ formation of biologically active steroids such as estradiol or androstenediol in tumor cells in hormone-dependent disease [6].

Numerous STS inhibitors have already been described in the literature and these have mainly focused on the sulfamate ester class of compound, first discovered by some of us [7]. Initial potent STS inhibitors were 
steroid-based: estrone and estradiol-based aryl sulfamate esters are known to be time and concentration dependent irreversible active-site directed inhibitors [8]. However, because of their very potent estrogenic activity in rodents they were not deemed suitable for progression as anti-tumor drug candidates, although one of them, estradiol 3-O-sulfamate (Figure 1, E2MATE), did reach phase II human clinical trials as a prodrug of estradiol in hormone replacement therapy $[9,10]$. E2MATE is still being pursued as a potential drug against the hormone-dependent disease endometriosis [11-12], that was shown to have an important STS component [13].

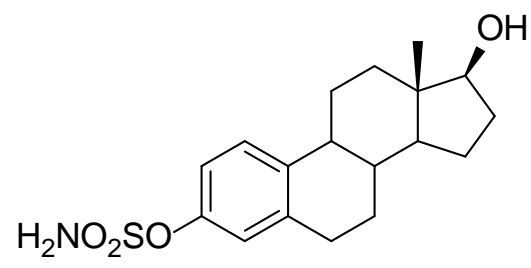

E2MATE<smiles>NS(=O)(=O)Oc1ccc2c3c(c(=O)oc2c1)CCCCC3</smiles>

Irosustat/STX64

Figure 1. Structures of the STS inhibitors E2MATE and Irosustat

While many further steroidal based sulfamate-based inhibitors have been designed $[9,14,15]$, because of estrogenicity issues the search for non-estrogenic STS inhibitors was prioritised and many structurally diverse inhibitors with different scaffolds combined with the sulfamate moiety have been reported $[1,9]$. Initially, those possessing a coumarin-based template were highly effective [16-18]. Coumarin-7-O-sulfamate and derivatives such as COUMATE showed high STS inhibitory activity and no significant estrogenicity [19]. Further development in this area led to the clinical STS inhibitor Irosustat/STX64 (Figure 1) [2, 17]. Such aryl sulfamate derivatives in particular have proved to be the most potent STS inhibitors and have reached clinical trials $[9,10]$. The most recent clinical reports relate to two studies, one with Irosustat in combination with an aromatase inhibitor [20] and another demonstrating the first effects of Irosustat in early breast cancer in treatment-naïve patients [21]. Aryl sulfamate-based drugs are thought to work by sulfamoyl group transfer to the active site hydrated formylglycine residue important for catalysis by STS, leading to irreversible inactivation of the enzyme [10].

Further work on STS inhibitor development included synthesizing reversible inhibitors without a sulfamate moiety, although these have not reached clinical evaluation [22, 23]. Other types of irreversible inhibitors that can produce reactive quinone methides upon activation by STS [24] and other alternatives to the sulfamate ester approach [25-27] have been investigated. Dual inhibitors of both STS and aromatase have also been reported, some with dual picomolar potency against both enzymes [28]. Sulfamate analogs of $N$ acylated tyramine containing $\mathrm{C}-\mathrm{F}$ bonds demonstrate that introduction of a fluorine atom into tyraminebased STS inhibitors remote from the aryl sulfamate moiety can enhance inhibitory activity, albeit in the micromolar range [29]. Recent work by some of us has shown that the introduction of halogens, particularly fluorine into the aryl sulfamate ring can appreciably improve the activity of STS inhibitors by lowering the 
pKa of the leaving phenol after transfer of the sulfamoyl moiety, thus increasing the "sulfamoyl-transfer potential" of the inhibitor $[9,10,30]$.

Non-steroidal STS inhibitors have often included a sulfamoylated fused $A B$ phenolic ring steroid surrogate motif, although early examples with employing single ring also showed good potency [31, 32] as did that using a single ring of a biphenyl template [33]. Recently, some of us explored further development of nonfused aryl sulfamate esters as potential STS inhibitors. Thus, simple arylamide derivatives A possessing especially terminal sulfamate moieties (Figure 2 ) were synthesized. One compound with $n=2$ had an $I_{50}$ of $421 \mathrm{nM}$ and was an effective STS inhibitor in whole cells, showing potential for further optimization [34].<smiles>N#CC1CCCC1C(=O)Nc1ccc(OS(N)(=O)=O)cc1</smiles>

A<smiles>[R][14c]1ccc(O[R5](N)=O)c(NC(=O)N2CCN([R])CC2)c1</smiles>

New series

Figure 2. Structures of arylamide sulfamates (A) and design of the new piperazino ureido sulfamates of this paper.

In the present study, we explored a series of broadly related piperazinylureas bearing the arylsulfamate moiety to further optimize this lead. In an effort to define the critical requirements for activity and understand the molecular determinants of such novel STS inhibitors, our approaches involved making structural modifications in the putative key pharmacophoric portions of the molecule. Our starting approach was focused upon synthesizing a series of sulfamate derivatives bearing on their scaffold a large number of aliphatic/aromatic/heterocyclic moieties (substituting the second nitrogen atom from the piperazine ring) in order to generate chemical diversity and to incorporate a piperazine group to improve physicochemical properties. Starting from the compound A, the amide moiety was replaced with an ureido group to allow strong hydrogen bonding which might lead to cooperative effects $[35,36]$. Furthermore, the ureido linker was connected to a more rigid heterocyclic system, the $\mathrm{N}$-substituted piperazine ring. Piperazine ring is a well-known heterocyclic structure present in many biologically active molecules. Constraining the polar nitrogen atoms into the piperazine ring can confer more drug-like properties to molecules and enhance favourable interactions with macromolecules [37, 38]. Herein we report the synthesis of a series of these ligands and in vitro results of an STS inhibition study using the lysate of JEG-3, a human placenta choriocarcinoma cell line known to have high STS activity. Additionally, membrane permeability was explored using STS inhibition in intact JEG-3 cells.

\section{Results and discussion}

\subsection{Chemistry}

The synthesis of the new compounds is reported in Schemes 1 and 2. Hydroxyarylcarbamates 3 were obtained with good yields by reacting 4-hydroxyarylamines $\mathbf{1}$ with phenylchloroformate $\mathbf{2}$ in the presence of 
$\mathrm{N}, \mathrm{N}$-diisopropylethylamine (DIPEA). Sulfamoylation of aryl carbamates $\mathbf{3}$ upon treatment with sulfamoyl chloride [39] in $\mathrm{N}, \mathrm{N}$-dimethylacetamide (DMA) solution furnished the key intermediates $\mathbf{4}$. Coupling of $\mathbf{4}$ with 1-substituted piperazines in DMSO solution gave the piperazinyl urea derivatives 5-31 (Scheme 1).<smiles>[R16]Oc1ccc(NC(=O)N2CCN([R])CC2)[Y4]c1OS(=O)(=O)O[Na]</smiles>

1a-e

3a-e

4a-e

5a-e

$$
\begin{aligned}
& \begin{array}{l}
\mathbf{a} X=H \\
{ }_{b} X=3-F
\end{array} \\
& \text { c } \equiv \text { 2-pl } \\
& { }^{d} \mathrm{X}=2-\mathrm{Cl}
\end{aligned}
$$

Scheme 1. Reagents and conditions: (i) DIPEA, THF, r.t. 24 h; (ii) $\mathrm{ClSO}_{2} \mathrm{NH}_{2}$, DMA, r.t. 12 h; (iii) Substituted piperazine, DMSO, r.t. 24 h.

A pyrimidinyl-piperazinourea series 35-42 was synthesized by heterocyclization of 4-Boc-piperazine-1carboxamidine (32) with 3-(dimethylamino)propenones 33a-h in boiling 1-propanol, followed by trifluoroacetic acid (TFA)-mediated deprotection in dichloromethane (DCM) solution and then coupling with 4-((phenoxycarbonyl)amino)phenyl sulfamate (4a) (Scheme 2).

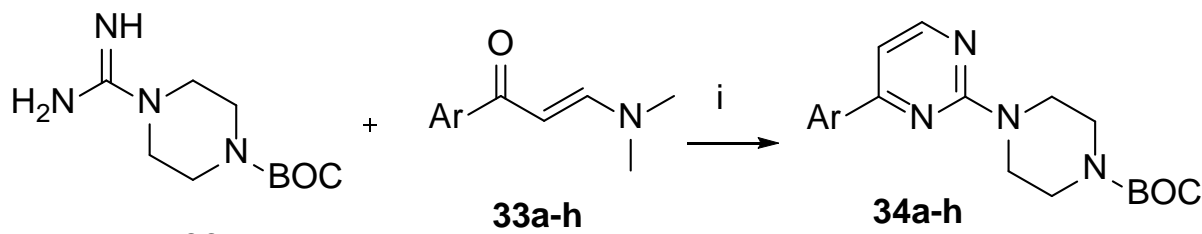

32

$\mathbf{a}^{\mathrm{Ar}}=\mathrm{C}_{6} \mathrm{H}_{5}$

b $\mathrm{Ar}=4-\mathrm{OMeC}_{6} \mathrm{H}_{4}$

c Ar $\equiv$ 3-B-BHo $\mathrm{C}_{6} \mathrm{H}_{4}$

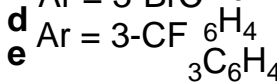

f $A_{A r}=3,34,($ (⿹)

${ }_{\mathbf{h}} \mathrm{Ar}=2$-benzofuraß $\mathrm{C}_{6} \mathrm{H}_{2}$<smiles>CC(C)(C)c1nccc(N2CCN(C(=O)Nc3ccc(OS(N)(=O)=O)cc3)CC2)n1</smiles>

Scheme 2. Reagents and conditions: (i) 1-propanol, reflux 12 h; (ii) TFA, DCM, r.t. 24 h; (iii) 4a, DIPEA, DMSO, r.t. $24 \mathrm{~h}$. 


\subsection{STS inhibition}

The in vitro STS inhibition of activity of the sulfamates 5-31 and 35-42 was measured in an assay using a JEG3 cell lysate. The in vitro inhibition results are reported as $\%$ of residual STS at $10 \mu \mathrm{M}$ inhibitor concentration (Tables 1, 2, and 3), and IC 50 values were determined in the relevant cases (Figures 4-6). Compounds showing strong STS inhibition were selected for whole cell experiments to assess the ability to cross a lipid bilayer using intact monolayers of JEG-3 cells (Figures 3 and 6).

Table 1. STS inhibitory activity of sulfamates of the hydroxyarylcarbamate series 5-18.<smiles>[R]N1CCN(C(=O)Nc2ccc(OS(N)(=O)=O)cc2)CC1</smiles>

Compound


15<smiles>CCc1cc2ccccc2o1</smiles>

16

17

18 $n$-heptyl

$n$-octyl

$n$-decyl
$20.2 \pm 0.7$

$27.7 \pm 1.6$

$12.4 \pm 2.7$

$3.5 \pm 0.7$

${ }^{a}$ Residual activity after JEG-3 cell lysate treatment with $10 \mu \mathrm{M}$ inhibitor is shown.

A

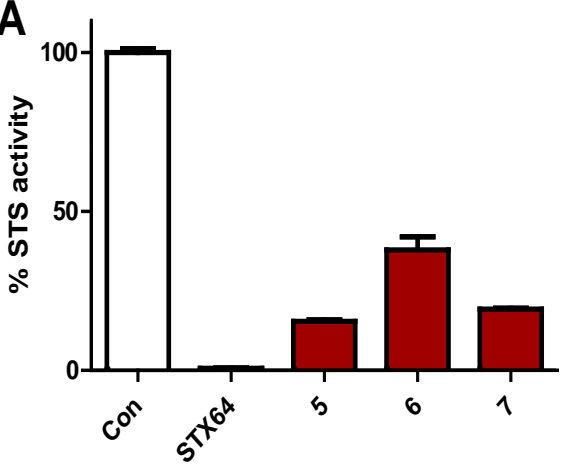

C

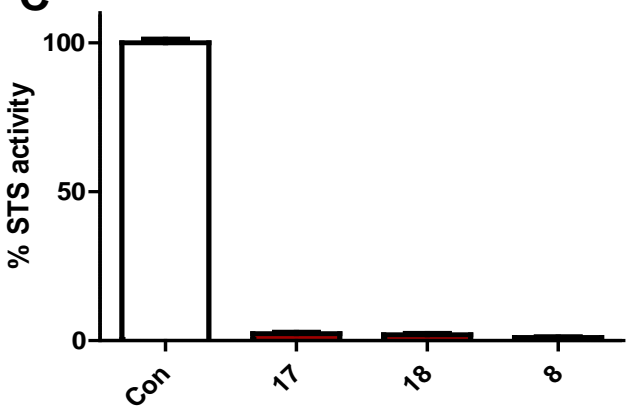

B

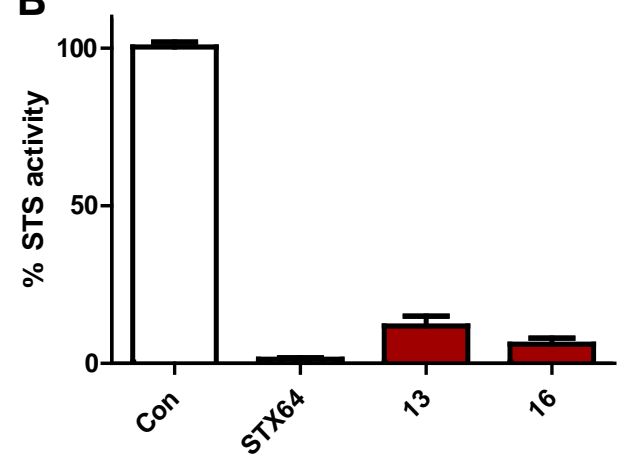

Figure 3. Evaluation of sulfamates 5-7 (A), 13 and $\mathbf{1 6}$ (B), 8, 17 and $\mathbf{1 8}(\mathrm{C})$ in whole cell JEG-3. All compounds were tested at $10 \mu \mathrm{M}$, the reference inhibitor STX64 was used as positive control. All data represents mean \pm S.D., $\mathrm{n}=3$

The following structure activity relationship (SAR) may be noted regarding the inhibition data of compounds 5-18 shown in Table 1 and Figure 3. The benzylpiperazine urea 5 showed good STS residual activity (18.7\% \pm $1.6)$ in isolated enzyme assay as well as in intact JEG-3 cells $(19.5 \% \pm 1.3)$. The removal of the methylene linker to give sulfamate 6 did not produce significant changes in inhibitory activity against the isolated enzyme, while the activity on JEG-3 was about a half as compared to compound $5(32.8 \% \pm 6.2)$. The introduction of a methyl group into 3-position of aromatic ring (compound 7) produced an increase in activity against isolated enzyme and cells $(23.4 \% \pm 1.1)$. The shift of the methyl group to the 2-position to give urea $\mathbf{9}$ highly reduced the activity. On the contrary, the introduction of a second methyl group as in compound $\mathbf{1 4}$ produced high activity on the isolated enzyme. The replacement of the 3-methyl group of compound $\mathbf{7}$ with a 3-methoxy group to give the urea $\mathbf{1 2}$ provided reduction of inhibitory activity as well as the shift of the 
methoxy into 4-position (urea 11). The 4-fluorine substituted urea 10 showed poor activity, while the replacement of the fluorine with a 4-chlorine atom afforded the high active urea 8 . The introduction of a second chlorine atom to give compound $\mathbf{1 3}$ produced reduction in activity on the isolated enzyme and 3.6\% \pm 2.3 on JEC-3 cells (Figure 3 ). The replacement of the benzyl group of compound $\mathbf{5}$ with a benzofurylmethyl (urea 15) did not afforded significant change in inhibitory activity. However, the replacement of the benzyl group with aliphatic chains to give compounds $\mathbf{1 6 - 1 8}$ produced good inhibitory activity being the potency of the ureas as much strong as the chain carbon atom number is increased. In summary, the best inhibitory activity was showed by the ureas bearing 4-chlorophenyl, 2,3-dimethylphenyl groups or aliphatic chains.

The compounds showing the best activity were evaluated for their $\mathrm{IC}_{50}$ values in STS inhibition (Table 4). Compounds 13 and 16 showed $\mathrm{IC}_{50}$ values of $1.23 \mu \mathrm{M}$ and $1.69 \mu \mathrm{M}$ respectively. While relatively modest, this was nevertheless encouraging, and further substitutions produced compounds in the nM potency range, ie 17, 18, 8 and 14 for which $I_{50}$ values were determined as $43.7 \mathrm{nM}, 33.2 \mathrm{nM}, 94.0 \mathrm{nM}$ and $66.0 \mathrm{nM}$ respectively (Figure 4).
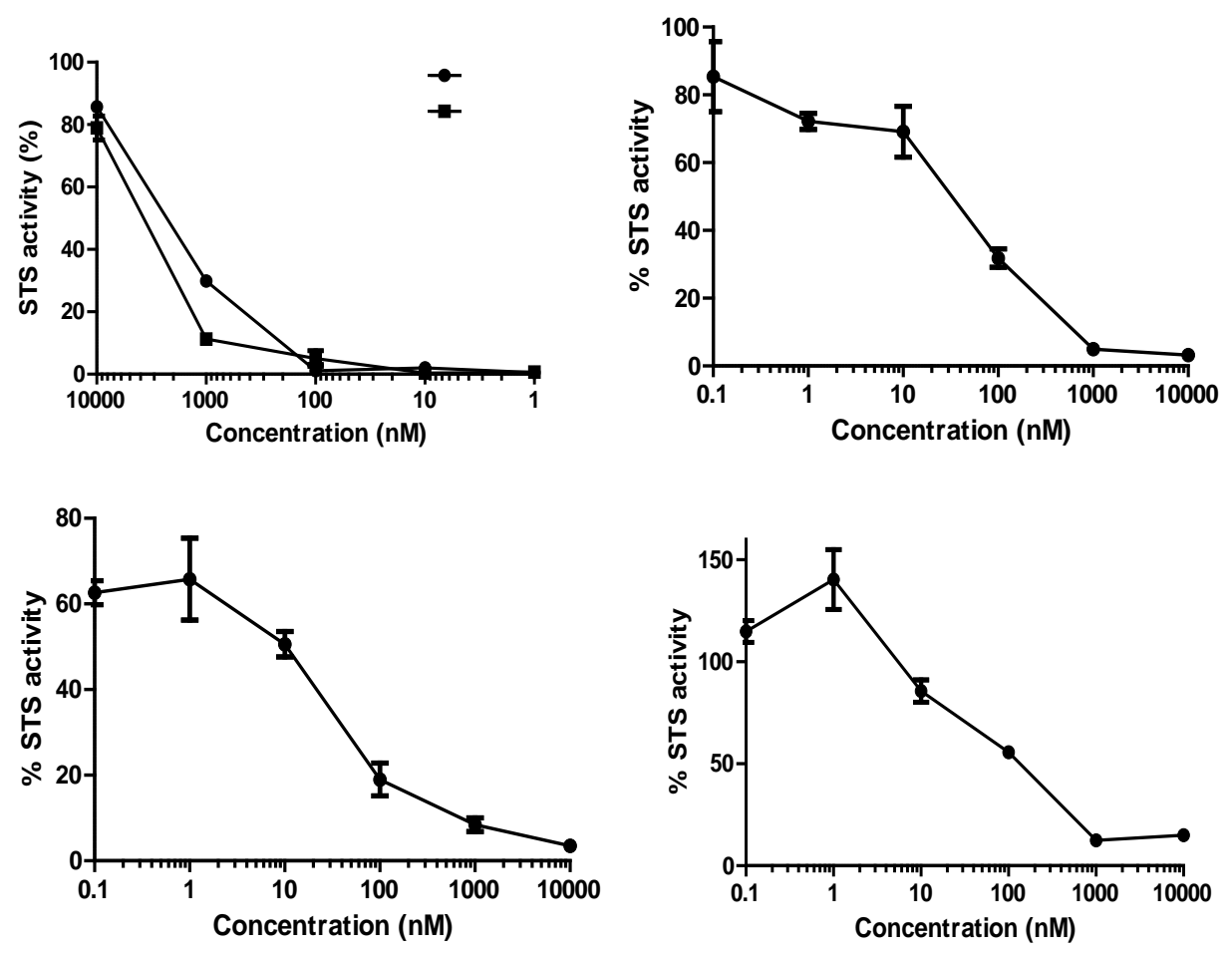

Figure $4 . \mathrm{IC}_{50}$ of STS inhibition determined for sulfamates $\mathbf{8}, \mathbf{1 3}, \mathbf{1 6}, \mathbf{1 7}$, and $\mathbf{1 8}$, using JEG-3 protein. All data represents mean \pm S.D., $n=3$

It has been reported that introduction of fluorine atoms into of biologically active compounds is a strategy to enhance their activity and to modify their absorption, distribution, metabolism, and excretion. In general, $\mathrm{H} / \mathrm{F}$ exchange produces a more lipophilic molecule. Moreover, in the case of STS inhibitors possessing the aryl sulfamate pharmacophore generally substitution of the aromatic ring with electron-withdrawing groups including halogenation, even when not directly on the ring, lowers the pKa of the departing phenolic group 
in the irreversible inhibition process and invariably increases overall potency considerably. Thus, we designed a second series of ureas bearing substituted moieties unchanged but introducing fluorine and chlorine atoms on the sulfamoylated aromatic ring (Table 2, 4 and Figure 5).

Table 2. STS inhibitory activity of sulfamates of the hydroxyarylcarbamate series 19-31.

\begin{tabular}{|c|c|c|c|}
\hline Compound & $\mathbf{x}$ & $\mathbf{R}$ & Residual STS \% activity \pm SD \\
\hline 19 & $2-\mathrm{F}$ & & $7.1 \pm 0.7$ \\
\hline 20 & $2-\mathrm{F}$ & $n$-octyl & $11.4 \pm 0.8$ \\
\hline 21 & $2-\mathrm{F}$ & $n$-decyl & $15.2 \pm 3.3$ \\
\hline 22 & $2-\mathrm{Cl}$ & & $110 \pm 10.8$ \\
\hline 23 & $2-\mathrm{Cl}$ & & $15.1 \pm 0.2$ \\
\hline 24 & $2-\mathrm{Cl}$ & n-octyl & $13.9 \pm 1.5$ \\
\hline 25 & $2-\mathrm{Cl}$ & $n$-decyl & $25.4 \pm 0.4$ \\
\hline 26 & $3-F$ & & $107.9 \pm 6.2$ \\
\hline 27 & $3-\mathrm{F}$ & CF & $108.8 \pm 3.2$ \\
\hline 28 & $3-F$ & $n$-octyl & $29.6 \pm 1.2$ \\
\hline 29 & $3-F$ & $n$-decyl & $7.8 \pm 1.2$ \\
\hline 30 & $3-\mathrm{Cl}$ & $n$-octyl & $71.6 \pm 4.8$ \\
\hline 31 & $3-\mathrm{Cl}$ & $n$-decyl & $102.1 \pm 3.5$ \\
\hline
\end{tabular}

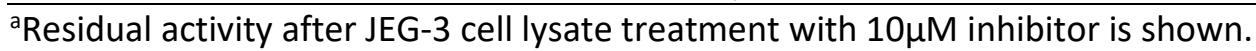



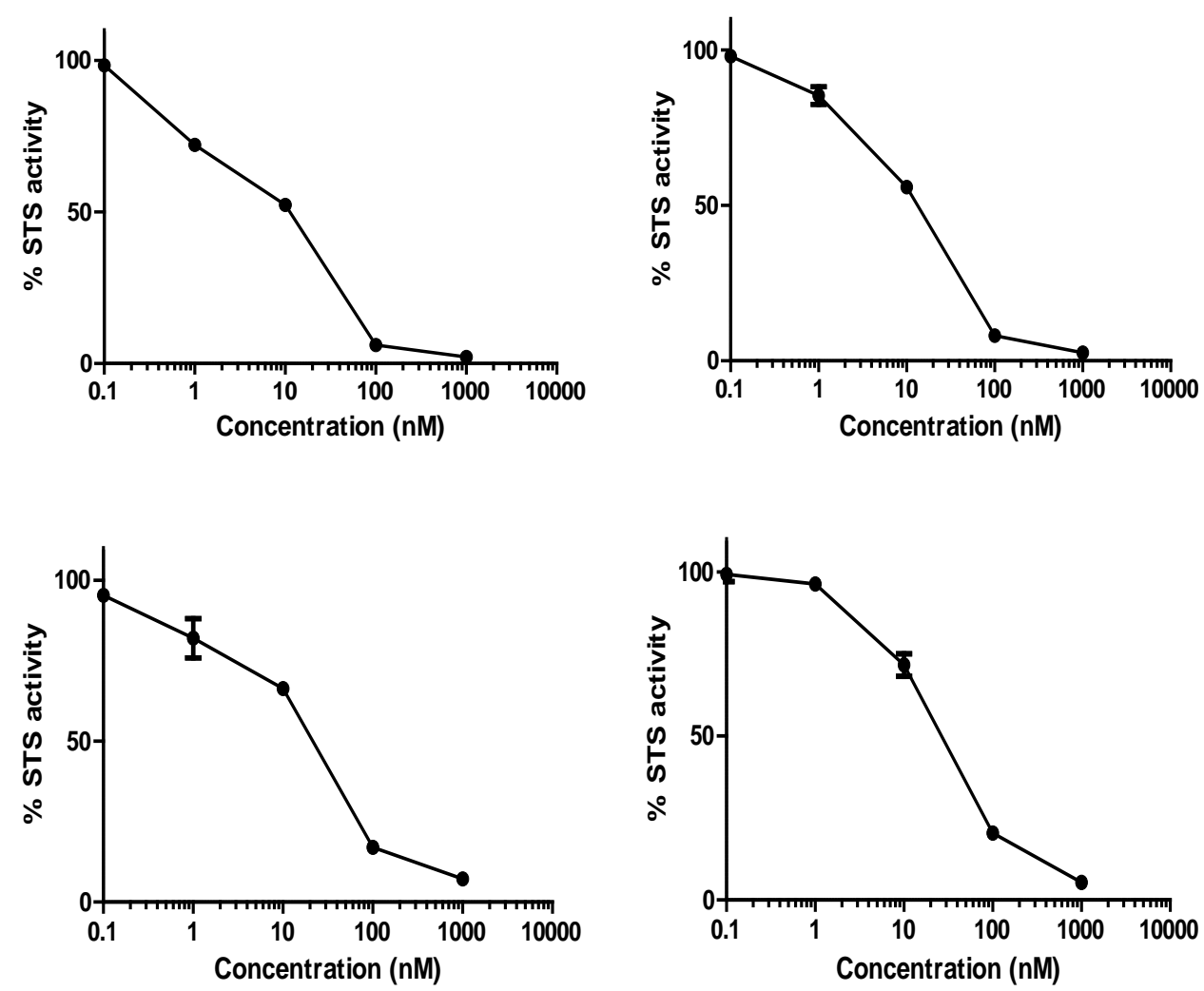

Figure 5. The $\mathrm{IC}_{50}$ of the most potent haloarylcarbamate sulfamates $(\mathbf{1 9}, \mathbf{2 0}, \mathbf{2 3}$ and $\mathbf{2 4})$ determined using JEG-3 protein. All data represents mean \pm S.D., $n=3$

The introduction of a 2-fluorine atom indeed produced an expected improvement in activity as shown by the paired comparison of the activity of compound 8 ( $\left(C_{50} 94 \mathrm{nM}\right)$ with compound 19 (IC $\left.5.1 \mathrm{nM}\right)$ activity and compound 17 ( $\left(C_{50} 43.7 \mathrm{nM}\right)$ with compound 20 ( $\left(\mathrm{C}_{50} 8.8 \mathrm{nM}\right)$. On the contrary, compound 18 shows high activity as compared with the fluorine analog $\mathbf{2 1}$. The replacement of the 2-fluorine with a 2-chlorine produced variable results. Compound $22(110 \% \pm 10.8)$ is about ten times less active as compared to the unsubstituted analog $8(14.9 \% \pm 1.6)$. The comparison of urea $14\left(I C_{50} 66 n M\right)$ and urea $23\left(I C_{50} 17 \mathrm{nM}\right)$ activity indicated a positive effect of the chlorine atom on the inhibitory activity. The comparison of compound 20 and compound 24 ( $\mathrm{IC}_{50} 18.9 \mathrm{nM}$ ) indicated a slight reduction in inhibitory activity, while the activity drop in compound $25(25.4 \% \pm 0.4)$ confirming the trend showed by the comparison of compounds 18 and $\mathbf{2 1}$. The shift on fluorine or chlorine atoms into 3-position led reduction in activity as compared with the unsubstituted analogs and the corresponding 2-fluorine or 2-chlorine isomers except for compound $\mathbf{2 9}$ ( $7.8 \%$ $\pm 1.2)$ that showed better than the isomer $21(15.2 \% \pm 3.3)$. Thus, final optimisation yielded a set of low $n M$ potent halogenated inhibitors, two of which 19 and 20 with $\mathrm{IC}_{50}$ values of 5.1 and $8.8 \mathrm{nM}$ respectively seem ideally suited for further development. 
The third series of ureidosulfamates was designed by introduction on the piperazine nitrogen of 6arylpyrimidine moieties and led to ureas 35-41 showing STS residual activity ranging from 7.9 to $60.7 \%$ (Table 3).

Table 3. STS inhibitory activity of sulfamates 35-42.<smiles>NS(=O)(=O)Oc1ccc(NC(=O)N2CCN(c3nccc(Br)n3)CC2)cc1</smiles>

Compound

${ }^{\mathrm{a}}$ Residual activity after JEG-3 cell lysate treatment with $10 \mu \mathrm{M}$ inhibitor is shown. 

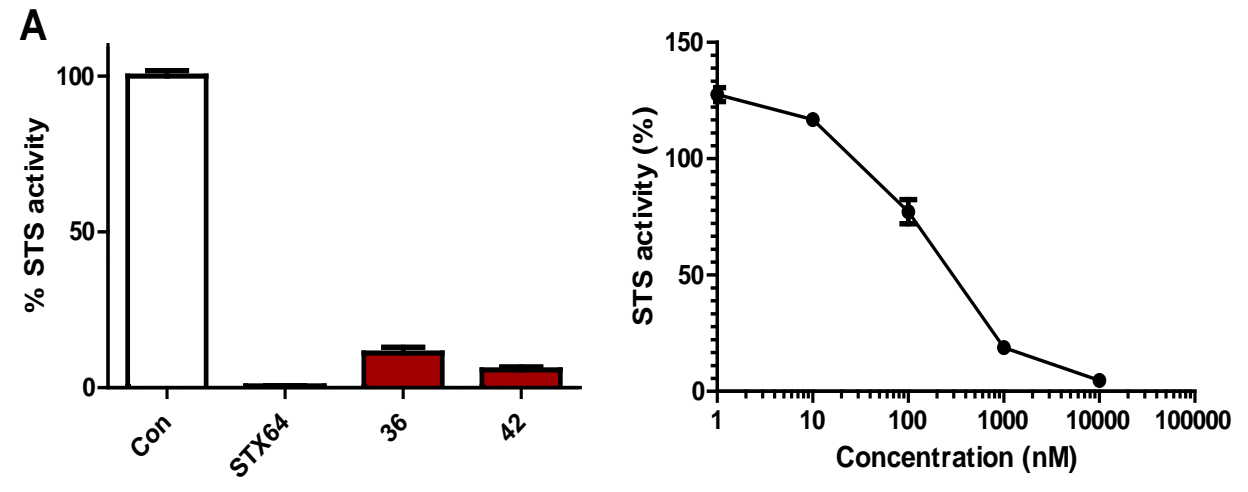

Figure 6. A) Evaluation of the STS inhibitory activity of sulfamate compounds $\mathbf{3 6}$ and $\mathbf{4 2}$ in whole cell JEG-3 tested at $10 \mu \mathrm{M}$, the reference inhibitor STX64 was used as positive control. B) STS inhibition IC 50 value of compound $\mathbf{4 2}$ determined using JEG-3 protein. All data represents mean \pm S.D., $n=3$.

The best activity in the case of a single aryl substitution was shown by the 4-methoxyphenyl urea $\mathbf{3 6}$ (7.9\% \pm 1.3 , HEC-3 $13.7 \% \pm 2.6$, Figure 6 ) both on isolated enzyme and whole cells. The introduction of further methoxy groups led to a slight reduction in activity as in compound $41(19.0 \% \pm 3.1)$ or a deep reduction of activity as in compound $\mathbf{4 0}(60.7 \% \pm 9.4)$. The removal of substituents as in compound $\mathbf{3 5}$ or the introduction of substituents into the 3-position to afford ureas 37-39 produced reduction of activity. The replacement of the aryl ring on the pyrimidine with a benzofuran ring to give compound $\mathbf{4 2}(4.7 \% \pm 0.7)$ produced a high increase in activity as compared to compound 36 especially in JEG-3 cells $(4.1 \% \pm 0.9)$. With this encouraging potency sulfamate $\mathbf{4 2}$ was thus chosen for $\mathrm{IC}_{50}$ evaluation and it exhibited a value of $139 \mathrm{nM}$ (Figure 6) which already surpassed that of compound class $\mathbf{A}$ [34]. $\mathrm{IC}_{50}$ values for the most optimized compounds are shown collected in Table 4.

Table 4. Summary IC 50 values for STS inhibition

130162




$172-\mathrm{F}$

\section{Conclusions}

Following on from an initial arylamide series of aryl sulfamate-based inhibitors of steroid sulfatase of moderate potency two new series of piperazinyl-ureido aryl sulfamate-based STS inhibitors were designed and synthesized. Hydroxyarylcarbamates $\mathbf{3}$ were obtained by reacting 4-hydroxyarylamines with phenylchloroformate and subsequent sulfamoylation and coupling of the product with 1-substituted piperazines to give piperazinyl urea derivatives 5-31. A pyrimidinyl-piperazinourea series $\mathbf{3 5 - 4 2}$ was also synthesized by heterocyclization of 4-Boc-piperazine-1-carboxamidine with 3-(dimethylamino)propenones, followed by deprotection and subsequent coupling with the sulfamoylated building block. The ability of the target compounds both to inhibit STS in vitro using a JEG-3 human placenta choriocarcinoma cell line lysate and to inhibit STS in a whole cell evaluation of membrane permeability was explored using STS inhibition in intact JEG-3 cells. SAR conclusions were drawn from both series and a progression from the micromolar through to nanomolar inhibition level was achieved by varying substitution patterns. Selected compounds were chosen for final optimization through arylsulfamate ring substitution with halogens. Ultimately, four compounds of low nanomolar potency were achieved and two of these 19 and 20 with IC 50 values of 5.1 and $8.8 \mathrm{nM}$ respectively are attractive for further development and potential in vivo evaluation. Thus, the replacement of arylamide moiety with a piperazinyl-ureido group high increases STS inhibitory activity and piperazinyl-ureido aryl sulfamate derivatives represent an attractive new class of STS inhibitors.

\section{Experimental section}

\subsection{General methods}

All commercially available solvents and reagents were used without further purification. NMR spectra were recorded on an Inova 500 spectrometer (Varian, Palo Alto, CA, USA). The chemical shifts are reported in part per million downfield from tetramethylsilane (TMS) and the spectra were recorded in hexadeuteriodimethylsulphoxide $\left(\right.$ DMSO- $\left._{6}\right)$. Infrared spectra were recorded on a Vector 22 spectrometer 
(Bruker, Bremen, Germany) in Nujol mulls. The main bands are given in $\mathrm{cm}^{-1}$. Positive-ion electrospray ionization (ESI) mass spectra were recorded on a double-focusing MAT 95 instrument (Finnigan, Waltham, $\mathrm{MA}, \mathrm{USA}$ ) with BE geometry. Melting points $(\mathrm{mp})$ were determined with a SMP1 Melting Point apparatus (Stuart Scientific, Stone, UK) and are uncorrected. All products reported showed spectral data in agreement with the assigned structures. The purity of the tested compounds was determined by combustion elemental analyses conducted by the Microanalytical Laboratory of the Chemistry Department of the University of Ferrara with a MT-5 CHN recorder elemental analyser (Yanagimoto, Kyoto, Japan) and the values found were within $0.4 \%$ of theoretical values. 4-(Phenoxycarbonyl)aminophenylsulfamate 4a [36], 4-Boc-piperazine-1carboxamidine 32 [37] and sulfamates 5-8, 10-12, 14, 35-39, 41, 42 [38] were synthesized as previously described.

\subsection{Chemistry}

\subsubsection{1-(Benzofuran-2-ylmethyl)piperazine}

To a solution of $N$-Boc-piperazine $(0.13 \mathrm{~g}, 0.7 \mathrm{mmol})$ in $\mathrm{CH}_{2} \mathrm{Cl}_{2}(10 \mathrm{~mL})$ benzofuran-2-carboxaldehyde $(0.13$ $\mathrm{mL}, 1.1 \mathrm{mmol})$, sodium $\mathrm{NaHCO}_{3}(0.07 \mathrm{~g}, 0.84 \mathrm{mmol})$ and sodium triacetoxyborohydride $(0.21 \mathrm{~g}, 1 \mathrm{mmol})$ were added; the mixture was then stirred at r.t. for $48 \mathrm{~h}$. Then the reaction mixture was basified to $\mathrm{pH} 10$ with a solution of $\mathrm{NaOH} 0.1 \mathrm{~N}$ and extracted with $\mathrm{CH}_{2} \mathrm{Cl}_{2}(3 \times 20 \mathrm{~mL})$. The organic phases were collected, dried over sodium $\mathrm{Na}_{2} \mathrm{SO}_{4}$, filtrated and the solvent removed to obtain the desired compound. The obtained residue was dissolved in dichloromethane $(10 \mathrm{~mL})$ without further purification, added trifluoroacetic acid $(5 \mathrm{~mL})$ and stirred at r.t. for $24 \mathrm{~h}$. Then the solvent was removed under vacuum and to the residue obtained diethyl ether $(20 \mathrm{~mL})$ was added, leading to formation of a solid that was filtered to give the title compound. Yield $74 \%$. M.p. $123-124{ }^{\circ} \mathrm{C} .{ }^{1} \mathrm{H}$ NMR (DMSO-d6) $\delta 2.76\left(\mathrm{~s}, 4 \mathrm{H}, \mathrm{CH}_{2}\right.$ ), $3.14\left(\mathrm{~s}, 4 \mathrm{H}, \mathrm{CH}_{2}, 3.87\left(\mathrm{~s}, 2 \mathrm{H}, \mathrm{CH}_{2}\right), 6.88(\mathrm{~s}, 1 \mathrm{H}, \mathrm{Ar}\right.$ ), $7.23(\mathrm{~d}, \mathrm{~J}=7.5 \mathrm{~Hz}, 1 \mathrm{H}, \mathrm{Ar}$ ), 7.29 (d, J = $8.0 \mathrm{~Hz}, 1 \mathrm{H}, \mathrm{Ar}$ ), 7.55 (d, J = $7.5 \mathrm{~Hz}, 1 \mathrm{H}, \mathrm{Ar}$ ), 7.62 (d, J = 8.0 Hz, $1 \mathrm{H}, \mathrm{Ar}$ ), $8.66\left(\mathrm{~s}, 1 \mathrm{H}, \mathrm{NH}\right.$ ). IR (Nujol) $1667 \mathrm{~cm}^{-1} . \mathrm{m} / \mathrm{z} 217(\mathrm{M}+\mathrm{H})^{+}$. Anal. Calcd. for $\mathrm{C}_{13} \mathrm{H}_{16} \mathrm{~N}_{2} \mathrm{O}(216.28) \mathrm{C}, 72.19 ; \mathrm{H}, 7.46$; $\mathrm{N}, 12.95$. Found \% C, 72.27; $\mathrm{H}, 7.48 ; \mathrm{N}, 12.91$.

\subsubsection{General procedure for the preparation of phenyl(4-hydroxylaryl)-carbamates (3b-e)}

To an ice-cooled stirred solution of the appropriate 4-hydroxyarylamine (5 mmol) and DIPEA (0.69 $\mathrm{mL}, 4$ $\mathrm{mmol})$ in anhydrous THF (10 ml) phenylchloroformiate $(0.5 \mathrm{~mL}, 4 \mathrm{mmol})$ was added dropwise. The reaction mixture was stirred at room temperature for 24 hours, then water $(100 \mathrm{~mL})$ was added; the mixture was stirred for additional $2 \mathrm{~h}$, the formed solid filtered off, and vacuum dried to give carbamates.

\subsubsection{Phenyl N-(3-fluoro-4-hydroxyphenyl)carbamate (3b)}

Following the general procedure, the title compound was prepared starting from 2-fluoro-4-hydroxyphenyl amine. Yield 88\%. M.p. $129-130{ }^{\circ} \mathrm{C} .{ }^{1} \mathrm{H}$ NMR (DMSO-d $\left.\mathrm{d}_{6}\right) 6.91(\mathrm{~m}, 1 \mathrm{H}, \mathrm{Ar}), 7.07$ (m, 1H, Ar), $7.21(\mathrm{~m}, 3 \mathrm{H}, \mathrm{Ar})$, 7.35 (m, 1H, Ar), 7.43 (m, 2H, Ar), 9.54 (s, 1H, NH), 10.09 (s, 1H, OH). IR (Nujol) 3321, 1718, $1615 \mathrm{~cm}^{-1} . \mathrm{m} / \mathrm{z}$ $248(\mathrm{M}+\mathrm{H})^{+}$. Anal. Calcd. for $\mathrm{C}_{13} \mathrm{H}_{10} \mathrm{FNO}_{3}(247.22) \mathrm{C}, 63.16 ; \mathrm{H}, 4.08 ; \mathrm{N}, 5.67$. Found $\mathrm{C}, 63.23 ; \mathrm{H}, 4.06 ; \mathrm{N}, 5.70$. 


\subsubsection{Phenyl N-(3-chloro-4-hydroxyphenyl)carbamate (3c)}

Following the general procedure, the title compound was prepared starting from 3-chloro-4-hydroxyphenyl amine. Yield 79\%. M.p. 132-133 ${ }^{\circ} \mathrm{C} .{ }^{1} \mathrm{H}$ NMR (DMSO-d 6 ) $\delta 6.93(\mathrm{~m}, 1 \mathrm{H}, \mathrm{Ar}), 7.07(\mathrm{~m}, 1 \mathrm{H}, \mathrm{Ar}), 7.22(\mathrm{~m}, 2 \mathrm{H}, \mathrm{Ar})$, $7.36(\mathrm{~m}, 1 \mathrm{H}, \mathrm{Ar}), 7.43(\mathrm{~m}, 2 \mathrm{H}, \mathrm{Ar}), 7.52(\mathrm{~m}, 1 \mathrm{H}, \mathrm{Ar}), 9.89$ (s, 1H, NH), 10.07 (s, 1H, OH). IR (Nujol) 3385, 1776, 1716, $1597 \mathrm{~cm}^{-1} . \mathrm{m} / \mathrm{z} 264(\mathrm{M}+\mathrm{H})^{+}$. Anal. Calcd. for $\mathrm{C}_{13} \mathrm{H}_{10} \mathrm{ClNO}_{3}$ (263.68) C, 59.22; $\mathrm{H}, 3.82 ; \mathrm{N}, 5.31$. Found $\mathrm{C}$, $59.16 ; H, 3.84 ; N, 5.28$.

\subsubsection{Phenyl N-(2-fluoro-4-hydroxyphenyl)carbamate (3d)}

Following the general procedure, the title compound was prepared starting from 3-fluoro-4-hydroxyphenyl amine. Yield 90\%. M.p. $126-127^{\circ} \mathrm{C} .{ }^{1} \mathrm{H}$ NMR (DMSO-d $\left.\mathrm{d}_{6}\right) \delta 6.62(\mathrm{~m}, 2 \mathrm{H}, \mathrm{Ar}), 7.19(\mathrm{~m}, 2 \mathrm{H}, \mathrm{Ar}), 7.26(\mathrm{~m}, 2 \mathrm{H}, \mathrm{Ar})$, $7.41\left(\mathrm{~m}, 2 \mathrm{H}, \mathrm{Ar}\right.$ ), $9.52(\mathrm{~s}, 1 \mathrm{H}, \mathrm{NH}), 9.82(\mathrm{~s}, 1 \mathrm{H}, \mathrm{OH}) . \mathrm{IR}$ (Nujol) 3425, 3403, 1730, 1639, $1610 \mathrm{~cm}^{-1} . \mathrm{m} / \mathrm{z} 248$ (M $+\mathrm{H})^{+}$. Anal. Calcd. for $\mathrm{C}_{13} \mathrm{H}_{10} \mathrm{FNO}_{3}(247.22) \mathrm{C}, 63.16 ; \mathrm{H}, 4.08 ; \mathrm{N}, 5.67$. Found C, 63.09; $\mathrm{H}, 4.10 ; \mathrm{N}, 5.64$.

\subsubsection{Phenyl N-(2-chloro-4-hydroxyphenyl)carbamate (3e)}

Following the general procedure, the title compound was prepared starting from 2-chloro-4-hydroxyphenyl amine. Yield 90\%. M.p. $128-129^{\circ} \mathrm{C} .{ }^{1} \mathrm{H}$ NMR (DMSO- $\left.\mathrm{d}_{6}\right) \delta 6.76(\mathrm{~m}, 1 \mathrm{H}, \mathrm{Ar}), 6.90-7.41(\mathrm{~m}, 7 \mathrm{H}, \mathrm{Ar}), 9.30(\mathrm{~s}, 1 \mathrm{H}$, $\mathrm{NH}), 9.89(\mathrm{~s}, 1 \mathrm{H}, \mathrm{OH})$. IR (Nujol) 3379, 1736, 1698, $1615 \mathrm{~cm}^{-1} . \mathrm{m} / \mathrm{z} 264(\mathrm{M}+\mathrm{H})^{+}$. Anal. Calcd. for $\mathrm{C}_{13} \mathrm{H}_{10} \mathrm{ClNO}_{3}$ (263.68) C, 59.22; H, 3.82; N, 5.31. Found C, 59.28; H, 3.84; N, 5.35.

\subsubsection{General procedure for the preparation of 4-(phenoxycarbonyl)aminoarylsulfamate (4b-e)}

To a stirred solution of phenyl(4-hydroxylaryl)-carbamate $(5 \mathrm{mmol})$ in anhydrous DMA (10 $\mathrm{mL}, 114 \mathrm{mmol})$, freshly prepared sulfamoyl chloride $(0.81 \mathrm{~g}, 7 \mathrm{mmol})$ in DMA $(5 \mathrm{~mL}, \mathrm{mmol})$ was added dropwise in $30 \mathrm{~min}$. The mixture was stirred at room temperature overnight, then water $(20 \mathrm{~mL})$ was added. The mixture was stirred for an additional $2 \mathrm{~h}$, then the white solid formed was filtered off and dried to give sulfamates in good purity to be used in the next step without further purification.

\subsubsection{3-Chloro-4-((phenoxycarbonyl)amino)phenyl sulfamate (4b)}

Following the general procedure, the title compound was prepared starting from phenyl $\mathrm{N}$-(3-chloro-4hydroxyphenyl)carbamate. Yield 40\%. M.p. $109-110^{\circ} \mathrm{C} .{ }^{1} \mathrm{H}$ NMR (DMSO-d $\left.\mathrm{d}_{6}\right) \delta 6.75(\mathrm{~m}, 1 \mathrm{H}, \mathrm{Ar}), 6.89(\mathrm{~m}, 1 \mathrm{H}$, $\operatorname{Ar})$, 7.23-7.41 (m, 6H, Ar), 8.15 (s, 2H, NH $), 9.89$ (s, 1H, NH). IR (Nujol) 3319, 3224, 1738, $1588 \mathrm{~cm}^{-1} . \mathrm{m} / \mathrm{z} 343$ $(\mathrm{M}+\mathrm{H})^{+}$. Anal. Calcd. for $\mathrm{C}_{13} \mathrm{H}_{11} \mathrm{ClN}_{2} \mathrm{O}_{5} \mathrm{~S}(342.75) \mathrm{C}, 45.55 ; \mathrm{H}, 3.23 ; \mathrm{N}, 8.17$. Found $\mathrm{C}, 45.61 ; \mathrm{H}, 3.25 ; \mathrm{N}, 8.20$.

\subsubsection{2-Chloro-4-((phenoxycarbonyl)amino)phenyl sulfamate (4c)}

Following the general procedure, the title compound was prepared starting from phenyl N-(2-chloro-4hydroxyphenyl)carbamate. Yield 36\%. M.p. $120-121^{\circ} \mathrm{C}$. ${ }^{1} \mathrm{H}$ NMR (DMSO- $\left.\mathrm{d}_{6}\right) \delta 7.23(\mathrm{~m}, 3 \mathrm{H}, \mathrm{Ar}), 7.43(\mathrm{~m}, 4 \mathrm{H}$, $\operatorname{Ar}$ ), $7.71(\mathrm{~s}, 1 \mathrm{H}, \mathrm{Ar}), 8.17\left(\mathrm{~s}, 2 \mathrm{H}, \mathrm{NH}_{2}\right.$ ), $10.48(\mathrm{~s}, 1 \mathrm{H}, \mathrm{NH})$. IR (Nujol) 3302, 3216, 1752, $1591 \mathrm{~cm}^{-1} . \mathrm{m} / \mathrm{z} 343$ (M $+\mathrm{H})^{+}$. Anal. Calcd. for $\mathrm{C}_{13} \mathrm{H}_{11} \mathrm{ClN}_{2} \mathrm{O}_{5} \mathrm{~S}(342.75) \mathrm{C}, 45.55 ; \mathrm{H}, 3.23 ; \mathrm{N}, 8.17$. Found C, 45.49; H 3.24; N, 8.14.

\subsubsection{3-Fluoro-4-((phenoxycarbonyl)amino)phenyl sulfamate (4d)}

Following the general procedure, the title compound was prepared starting from phenyl (3-fluoro-4hydroxyphenyl)carbamate. Yield 62\%. M.p. $117-118^{\circ} \mathrm{C} .{ }^{1} \mathrm{H}$ NMR (DMSO-d 6$) \delta 6.44(\mathrm{~m}, 1 \mathrm{H}, \mathrm{Ar}), 6.76(\mathrm{~m}, 1 \mathrm{H}$, 
Ar), 7.31-7.36 (m, 6H, Ar), $8.20\left(\mathrm{~s}, 2 \mathrm{H}, \mathrm{NH}_{2}\right), 9.78$ (s, 1H, NH). IR (Nujol) 3315, 3222, 1743, $1579 \mathrm{~cm}^{-1} . \mathrm{m} / \mathrm{z} 327$ $(\mathrm{M}+\mathrm{H})^{+}$. Anal. Calcd. for $\mathrm{C}_{13} \mathrm{H}_{11} \mathrm{FN}_{2} \mathrm{O}_{5} \mathrm{~S}(326.30) \mathrm{C}, 47.85 ; \mathrm{H}, 3.40 ; \mathrm{N}, 8.59$. Found $\mathrm{C}, 47.92 ; \mathrm{H}, 3.38 ; \mathrm{N}$ 8.55.

\subsubsection{2-Fluoro-4-((phenoxycarbonyl)amino)phenyl sulfamate (4e)}

Following the general procedure, the title compound was prepared starting from phenyl (2-fluoro-4hydroxyphenyl)carbamate. Yield 56\%. M.p. $112-113^{\circ} \mathrm{C} .{ }^{1} \mathrm{H}$ NMR (DMSO- $\left.\mathrm{d}_{6}\right) \delta 7.27(\mathrm{~m}, 4 \mathrm{H}, \mathrm{Ar}), 7.42(\mathrm{~m}, 3 \mathrm{H}$, $\operatorname{Ar}$ ), $7.68\left(\mathrm{~d}, J=8.5 \mathrm{~Hz}, 1 \mathrm{H}, \mathrm{Ar}\right.$ ), $8.13\left(\mathrm{~s}, 2 \mathrm{H}, \mathrm{NH}_{2}\right.$ ), $9.81(\mathrm{~s}, 1 \mathrm{H}, \mathrm{NH}) . \mathrm{IR}$ (Nujol) 3322, 3238, 1744, $1587 \mathrm{~cm}^{-1} . \mathrm{m} / \mathrm{z}$ $327(\mathrm{M}+\mathrm{H})^{+}$. Anal. Calcd. for $\mathrm{C}_{13} \mathrm{H}_{11} \mathrm{FN}_{2} \mathrm{O}_{5} \mathrm{~S}(326,30) \mathrm{C}, 47.85 ; \mathrm{H}, 3.40 ; \mathrm{N}, 8.59$. Found C, 47.79; H, 3.39; N, 8.63.

\subsubsection{General procedure for the synthesis of 4-(piperazinocarbonyl)aminosulfamates (5-31)}

A mixture of 4-(phenoxycarbonyl)aminoarylsulfamate $(1 \mathrm{mmol})$ and substituted 1-substituted piperazine (1 mmol) and DIPEA $(0.5 \mathrm{mmol})$, in anhydrous DMSO $(3 \mathrm{~mL})$ was stirred at room temperature for $24 \mathrm{~h}$. Then, water $(10 \mathrm{~mL})$ was added and the mixture was stirred at room temperature until a solid is formed. The solid formed was filtered off, washed with water and air dried to give the title ureas.

\subsubsection{4-(4-(o-Tolyl)piperazine-1-carboxamido)phenyl sulfamate (9)}

Following the general procedure, the title compound was prepared starting from o-tolylpiperazine. Yield 72\%. M.p. 170-171 ${ }^{\circ} \mathrm{C} .{ }^{1} \mathrm{H}$ NMR (DMSO-d $\left.\mathrm{d}_{6}\right) \delta 2.29\left(\mathrm{~s}, 3 \mathrm{H}, \mathrm{CH}_{3}\right), 2.85\left(\mathrm{~s}, 4 \mathrm{H}, \mathrm{CH}_{2}\right), 3.60\left(\mathrm{~s}, 4 \mathrm{H}, \mathrm{CH}_{2}\right), 6.98(\mathrm{~d}, \mathrm{~J}=$ $7.0 \mathrm{~Hz}, 1 \mathrm{H}, \operatorname{Ar}$ ), 7.04 (d, J = 8.5 Hz, 1H, Ar), 7.15 (d, J = 8.0 Hz, 2H, Ar), 7.18 (d, J = 7.0 Hz, 2H, Ar), 7.52 (d, J = $8.0 \mathrm{~Hz}, 2 \mathrm{H}, \mathrm{Ar}$ ), $7.86\left(\mathrm{~s}, 2 \mathrm{H}, \mathrm{NH}_{2}\right.$ ), $8.70(\mathrm{~s}, 1 \mathrm{H}, \mathrm{NH}) .{ }^{13} \mathrm{C}$ NMR (DMSO-d $\left.\mathrm{d}_{6}\right) \delta 17.8,53.4(2 \mathrm{C}), 55.8(2 \mathrm{C}), 117.8$, 120.8 (2C), 125.2 (2C), 126.6, 127.1, 130.2, 133.6, 139.8, 146.2, 152.3, 157.9. IR (Nujol) 3329, 1647, $1535 \mathrm{~cm}^{-}$ 1. $\mathrm{m} / \mathrm{z} 391(\mathrm{M}+\mathrm{H})^{+}$. Anal. Calcd. for $\mathrm{C}_{18} \mathrm{H}_{22} \mathrm{~N}_{4} \mathrm{O}_{4} \mathrm{~S}(390,46) \mathrm{C}, 55.37 ; \mathrm{H}, 5.68 \mathrm{~N}, 14.35$. Found $\mathrm{C}, 55.30 ; \mathrm{H}, 5.66$; N, 14.37 .

\subsubsection{4-(4-(3,4-Dichlorophenyl)piperazine-1-carboxamido)phenyl sulfamate (13)}

Following the general procedure, the title compound was prepared starting from 3,4dichlorophenylpiperazine. Yield 98\%. M.p. $144-145^{\circ} \mathrm{C} .{ }^{1} \mathrm{H}$ NMR (DMSO- $\left.\mathrm{d}_{6}\right) \delta 3.23\left(\mathrm{~m}, 4 \mathrm{H}, \mathrm{CH}_{2}\right), 3.58(\mathrm{~m}, 4 \mathrm{H}$, $\left.\mathrm{CH}_{2}\right), 6,97(\mathrm{~s}, 1 \mathrm{H}, \mathrm{Ar}), 7.14(\mathrm{~d}, \mathrm{~J}=8.5 \mathrm{~Hz}, 2 \mathrm{H}, \mathrm{Ar}), 7.20(\mathrm{~m}, 2 \mathrm{H}, \mathrm{Ar}), 7.52(\mathrm{~d}, \mathrm{~J}=8.5 \mathrm{~Hz}, 2 \mathrm{H}, \mathrm{Ar}), 7.87\left(\mathrm{~s}, 2 \mathrm{H}, \mathrm{NH}_{2}\right)$, $8.72\left(\mathrm{~s}, 1 \mathrm{H}, \mathrm{NH}\right.$ ). ${ }^{13} \mathrm{C}$ NMR (DMSO-d 6 ) $\delta 52.3(2 \mathrm{C}), 53.2(2 \mathrm{C}), 111.2,114.2,122.4,122.9,123.6(2 \mathrm{C}), 127.5$, 133.0 (2C), 144.2, 144.8 (2C), 157.4. IR (Nujol) 3341, $1649 \mathrm{~cm}^{-1} . \mathrm{m} / \mathrm{z} 446(\mathrm{M}+\mathrm{H})^{+}$. Anal. Calcd. for $\mathrm{C}_{17} \mathrm{H}_{18} \mathrm{Cl}_{2} \mathrm{~N}_{4} \mathrm{O}_{4} \mathrm{~S}(445,32) \mathrm{C}, 45.85 ; \mathrm{H}, 4.07 ; \mathrm{N}, 12.58$. Found $\mathrm{C}, 45.92 ; \mathrm{H}, 4.05 ; \mathrm{N}, 12.62$.

\subsubsection{4-(4-(Benzofuran-2-ylmethyl)piperazine-1-carboxamido)phenyl sulfamate (15)}

Following the general procedure, the title compound was prepared starting from 1-(benzofuran-2ylmethyl)piperazine. Yield 40\%. M.p. 140-141 ${ }^{\circ} \mathrm{C} .{ }^{1} \mathrm{H}$ NMR (DMSO-d $\left.\mathrm{d}_{6}\right) \delta 2.54\left(\mathrm{~s}, 2 \mathrm{H}, \mathrm{CH}_{2}\right), 3.30\left(\mathrm{~m}, 4 \mathrm{H}, \mathrm{CH}_{2}\right)$, $3.51\left(\mathrm{~m}, 4 \mathrm{H}, \mathrm{CH}_{2}\right), 6.81(\mathrm{~s}, 1 \mathrm{H}, \mathrm{Ar}), 7.13(\mathrm{~d}, \mathrm{~J}=9.0 \mathrm{~Hz}, 1 \mathrm{H}, \operatorname{Ar}), 7.16(\mathrm{~d}, \mathrm{~J}=9.0 \mathrm{~Hz}, 1 \mathrm{H}, \operatorname{Ar}), 7.26(\mathrm{~d}, \mathrm{~J}=9.5 \mathrm{~Hz}$, $1 \mathrm{H}, \operatorname{Ar}), 7.43(\mathrm{~d}, \mathrm{~J}=7.0 \mathrm{~Hz}, 1 \mathrm{H}, \mathrm{Ar}), 7.46(\mathrm{~d}, \mathrm{~J}=7.0 \mathrm{~Hz}, 1 \mathrm{H}, \mathrm{Ar}), 7.49(\mathrm{~d}, \mathrm{~J}=9.5 \mathrm{~Hz}, 1 \mathrm{H}, \mathrm{Ar}), 7.47(\mathrm{~m}, 2 \mathrm{H}, \mathrm{Ar}$ ), $7.88\left(\mathrm{~s}, 2 \mathrm{H}, \mathrm{NH}_{2}\right), 8.61(\mathrm{~s}, 1 \mathrm{H}, \mathrm{NH}) .{ }^{13} \mathrm{C} \mathrm{NMR}\left(\mathrm{DMSO}_{-} \mathrm{d}_{6}\right) \delta 50.1(2 \mathrm{C}), 52.2(2 \mathrm{C}), 58.3,103.0,111.2,120.9(2 \mathrm{C})$, 
121.6, 123.4 (2C), 123.9, 125.2, 127.1, 131.8, 146.3, 155.1, 155.2, 157.4. IR (Nujol) 3386, $1645 \mathrm{~cm}^{-1} . \mathrm{m} / \mathrm{z} 431$ $(\mathrm{M}+\mathrm{H})^{+}$. Anal. Calcd. for $\mathrm{C}_{20} \mathrm{H}_{22} \mathrm{~N}_{4} \mathrm{O}_{5} \mathrm{~S}(430,13) \mathrm{C}, 55.80 ; \mathrm{H}, 5.15 ; \mathrm{N}, 13.02$. Found C, 55.73; $\mathrm{H}, 5.13 ; \mathrm{N}, 12.98$.

\subsubsection{4-(4-Hepty/piperazine-1-carboxamido)phenyl sulfamate (16)}

Following the general procedure, the title compound was prepared starting from $n$-heptylpiperazine. Yield 42\%. M.p. 114-115 ${ }^{\circ} \mathrm{C} .{ }^{1} \mathrm{H} N M R\left(D M S O ~ d_{6}\right) \delta 0.87\left(\mathrm{~m}, 3 \mathrm{H}, \mathrm{CH}_{3}\right), 1.28\left(\mathrm{~m}, 12 \mathrm{H}, \mathrm{CH}_{2}\right), 1.48\left(\mathrm{~m}, 2 \mathrm{H}, \mathrm{CH}_{2}\right), 3.29(\mathrm{~m}$, $\left.4 \mathrm{H}, \mathrm{CH}_{2}\right), 3.48\left(\mathrm{~m}, 2 \mathrm{H}, \mathrm{CH}_{2}\right), 7.14(\mathrm{~s}, 2 \mathrm{H}, \mathrm{Ar}), 7.48(\mathrm{~s}, 2 \mathrm{H}, \mathrm{Ar}), 7.86\left(\mathrm{~s}, 2 \mathrm{H}, \mathrm{NH}_{2}\right), 8.63(\mathrm{~s}, 1 \mathrm{H}, \mathrm{NH}) .{ }^{13} \mathrm{C} \mathrm{NMR}$ (DMSO-d $\mathrm{d}_{6}$ ) $\delta 14.4,23.2,26.8,28.4,29.6,32.2,51.8$ (2C), 56.8 (2C), 57.3, 121.1 (2C), 123.6 (2C), 132.5, 148.1, 156.2. IR (Nujol) 3348, 1642, $1538 \mathrm{~cm}^{-1}$. m/z $399(\mathrm{M}+\mathrm{H})^{+}$. Anal. Calcd. for $\mathrm{C}_{18} \mathrm{H}_{30} \mathrm{~N}_{4} \mathrm{O}_{4} \mathrm{~S}(398.52) \mathrm{C}, 54.25 ; \mathrm{H}$, 7.59; N, 14.06. Found C, 54.31; H, 7.57; N, 14.09 .

4.2.4.5. 4-(4-Octylpiperazine-1-carboxamido)phenyl sulfamate (17)

Following the general procedure, the title compound was prepared starting from $n$-octylpiperazine. Yield

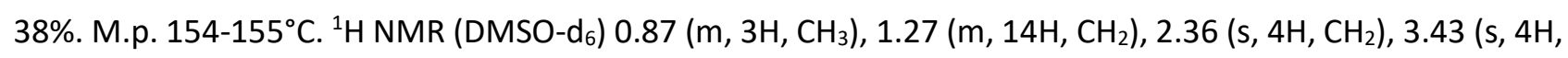
$\mathrm{CH}_{2}$ ), $7.14\left(\mathrm{~d}, \mathrm{~J}=7.0 \mathrm{~Hz}, 2 \mathrm{H}, \mathrm{Ar}\right.$ ), $7.49\left(\mathrm{~d}, \mathrm{~J}=7.5 \mathrm{~Hz}, 2 \mathrm{H}, \mathrm{Ar}\right.$ ), $7.86\left(\mathrm{~s}, 2 \mathrm{H}, \mathrm{NH}_{2}\right.$ ), 8.59 (s, $\left.1 \mathrm{H}, \mathrm{NH}\right) .{ }^{13} \mathrm{C}$ NMR (DMSO$\left.\mathrm{d}_{6}\right) \delta 17.1,25.2,30.1,31.8,32.0,34.4(2 \mathrm{C}), 42.3(2 \mathrm{C}), 55.8(2 \mathrm{C}), 60.9,123.5$ (2C), $125.2(2 \mathrm{C}), 142.1,147.6$, 158.0. IR (Nujol) 3373, $1642 \mathrm{~cm}^{-1}$. m/z $413(\mathrm{M}+\mathrm{H})^{+}$. Anal. Calcd. for $\mathrm{C}_{19} \mathrm{H}_{32} \mathrm{~N}_{4} \mathrm{O}_{4} \mathrm{~S}$ (412.55) C, 55.32; H, 7.82; N, 13.58. Found C, 55.27; H, 7.98; N, 13.62 .

\subsubsection{4-(4-Decylpiperazine-1-carboxamido)phenyl sulfamate (18)}

Following the general procedure, the title compound was prepared starting from $n$-decylpiperazine. Yield 51\%. M.p. 159-160 ${ }^{\circ} \mathrm{C} .{ }^{1} \mathrm{H}$ NMR (DMSO-d 6 ) $0.86\left(\mathrm{~m}, 3 \mathrm{H}, \mathrm{CH}_{3}\right), 1.26\left(\mathrm{~m}, 18 \mathrm{H}, \mathrm{CH}_{2}\right), 2.38\left(\mathrm{~s}, 4 \mathrm{H}, \mathrm{CH}_{2}\right), 3.44(\mathrm{~s}, 4 \mathrm{H}$, $\mathrm{CH}_{2}$ ), $7.13\left(\mathrm{~d}, \mathrm{~J}=9.0 \mathrm{~Hz}, 2 \mathrm{H}, \mathrm{Ar}\right.$ ), $7.50\left(\mathrm{~d}, \mathrm{~J}=9.0 \mathrm{~Hz}, 2 \mathrm{H}, \mathrm{Ar}\right.$ ), $7.86\left(\mathrm{~s}, 2 \mathrm{H}, \mathrm{NH}_{2}\right), 8.60(\mathrm{~s}, 1 \mathrm{H}, \mathrm{NH}) .{ }^{13} \mathrm{C}$ NMR (DMSO$\left.\mathrm{d}_{6}\right) \delta 17.1,25.3,31.8(2 \mathrm{C}), 32.1(2 \mathrm{C}), 32.2,34.5(2 \mathrm{C}), 42.5(2 \mathrm{C}), 46.7(2 \mathrm{C}), 60.9,123.5(2 \mathrm{C}), 125.2(2 \mathrm{C}), 142.1$, 147.6, 157.9.IR (Nujol) 3388, $1642 \mathrm{~cm}^{-1} . \mathrm{m} / \mathrm{z} 441(\mathrm{M}+\mathrm{H})^{+}$. Anal. Calcd. for $\mathrm{C}_{21} \mathrm{H}_{36} \mathrm{~N}_{4} \mathrm{O}_{4} \mathrm{~S}(440.60) \mathrm{C}, 57.25 ; \mathrm{H}$, 8.24; N, 12.72. Found C, 55.19; $H, 8.21 ; \mathrm{N}, 12.76$.

\subsubsection{4-(4-(4-Chlorophenyl)piperazine-1-carboxamido)-2-fluorophenyl sulfamate (19)}

Following the general procedure, the title compound was prepared starting from 4-(chlorophenyl)piperazine. Yield 90\%. M.p. $102-103^{\circ} \mathrm{C} .{ }^{1} \mathrm{H}$ NMR (DMSO-d $\left.\mathrm{d}_{6}\right) \delta 3.17\left(\mathrm{~s}, 4 \mathrm{H}, \mathrm{CH}_{2}\right), 3.60\left(\mathrm{~s}, 4 \mathrm{H}, \mathrm{CH}_{2}\right), 6.84(\mathrm{~m}, 1 \mathrm{H}, \mathrm{Ar}$ ), 7.00 (d, $\mathrm{J}=8.0 \mathrm{~Hz}, 2 \mathrm{H}, \mathrm{Ar}), 7.26(\mathrm{~d}, \mathrm{~J}=8.0 \mathrm{~Hz}, 2 \mathrm{H}, \mathrm{Ar}), 7.29(\mathrm{~m}, 1 \mathrm{H}, \mathrm{Ar}), 7.41(\mathrm{~m}, 1 \mathrm{H}, \mathrm{Ar}), 8.09\left(\mathrm{~s}, 2 \mathrm{H}, \mathrm{NH}_{2}\right), 8.99(\mathrm{~s}, 1 \mathrm{H}$, $\mathrm{NH}) .{ }^{13} \mathrm{C}$ NMR (DMSO-d $) \delta 42.6(2 \mathrm{C}), 51.2(2 \mathrm{C}), 111.6\left(\mathrm{~d},{ }^{2} \mathrm{~J}_{\mathrm{CF}}=19.1 \mathrm{~Hz}\right), 117.8\left(\mathrm{~d},{ }^{3} \mathrm{~J}_{\mathrm{CF}}=8.3 \mathrm{~Hz}\right), 119.1\left(\mathrm{~d},{ }^{4} \mathrm{~J}_{\mathrm{CF}}\right.$ $=3.5 \mathrm{~Hz}), 120.3(2 \mathrm{C}), 125.8,131.8(2 \mathrm{C}), 134.4\left(\mathrm{~d},{ }^{2} \mathrm{~J}_{\mathrm{CF}}=13.4 \mathrm{~Hz}\right), 135.6\left(\mathrm{~d},{ }^{3} \mathrm{~J}_{\mathrm{CF}}=9.5 \mathrm{~Hz}\right), 142.7,157.9\left(\mathrm{~d},{ }^{1} \mathrm{~J}_{\mathrm{CF}}=\right.$ 242.1 Hz), 158.2. IR (Nujol) 3325, 1645, $1605 \mathrm{~cm}^{-1} . \mathrm{m} / \mathrm{z} 429(\mathrm{M}+\mathrm{H})^{+}$. Anal. Calcd. for $\mathrm{C}_{17} \mathrm{H}_{18} \mathrm{ClFN}_{4} \mathrm{O}_{4} \mathrm{~S}(428.87)$ C, 47.61; H, 4.23; N, 13.06, Found C, 47.66; H, 4.21; N, 13.10.

\subsubsection{2-Fluoro-4-(4-octylpiperazine-1-carboxamido)phenyl sulfamate (20)}

Following the general procedure, the title compound was prepared starting from 4-octylpiperazine. Yield 15\%. M.p. 86-87 ${ }^{\circ} \mathrm{C} .{ }^{1} \mathrm{H}$ NMR (DMSO-d $\left.\mathrm{d}_{6}\right) \delta 0.87\left(\mathrm{t}, \mathrm{J}=6.5 \mathrm{~Hz}, 3 \mathrm{H}, \mathrm{CH}_{3}\right), 1.27\left(\mathrm{~m}, 14 \mathrm{H}, \mathrm{CH}_{2}\right), 2.38\left(\mathrm{~s}, 4 \mathrm{H}, \mathrm{CH}_{2}\right)$, $3.43\left(\mathrm{~s}, 4 \mathrm{H}, \mathrm{CH}_{2}\right), 6.81(\mathrm{~m}, 1 \mathrm{H}, \mathrm{Ar}), 7.00(\mathrm{~m}, 1 \mathrm{H}, \mathrm{Ar}), 7.32(\mathrm{~m}, 1 \mathrm{H}, \mathrm{Ar}), 7.41\left(\mathrm{~s}, 2 \mathrm{H}, \mathrm{NH}_{2}\right), 8.40(\mathrm{~s}, 1 \mathrm{H}, \mathrm{NH}) .{ }^{13} \mathrm{C}$ 
NMR (DMSO- $\left.\mathrm{d}_{6}\right) \delta 17.0,25.2,28.9,30.0,31.8,34.4(2 \mathrm{C}), 46.4(2 \mathrm{C}), 55.6(2 \mathrm{C}), 60.7,111.6\left(\mathrm{~d},{ }^{2} \mathrm{~J}_{\mathrm{CF}}=22.9 \mathrm{~Hz}\right)$, $119.0\left(\mathrm{~d},{ }^{3} \mathrm{~J}_{\mathrm{CF}}=6.1 \mathrm{~Hz}\right), 120.2\left(\mathrm{~d},{ }^{4} \mathrm{~J}_{\mathrm{CF}}=3.9 \mathrm{~Hz}\right), 135.6\left(\mathrm{~d},{ }^{3} \mathrm{~J}_{\mathrm{CF}}=8.6 \mathrm{~Hz}\right), 142.5\left(\mathrm{~d},{ }^{2} \mathrm{~J}_{\mathrm{CF}}=12.4 \mathrm{~Hz}\right), 154.3\left(\mathrm{~d},{ }^{1} \mathrm{~J}_{\mathrm{CF}}=\right.$ 229.8 Hz), 158.1. IR (Nujol) 3323, 1643, $1605 \mathrm{~cm}^{-1} . \mathrm{m} / \mathrm{z} 431(\mathrm{M}+\mathrm{H})^{+}$. Anal. Calcd. for $\mathrm{C}_{19} \mathrm{H}_{31} \mathrm{FN}_{4} \mathrm{O}_{4} \mathrm{~S}(430.54)$ C, 53.00; H, 7.26; N, 13.01. Found C, 53.05; H, 7.24; N, 12.97 .

\subsubsection{4-(4-Decylpiperazine-1-carboxamido)-2-fluorophenyl sulfamate (21)}

Following the general procedure, the title compound was prepared starting from 4-decylpiperazine. Yield 22\%. M.p. 48-49 ${ }^{\circ} \mathrm{C} .{ }^{1} \mathrm{H}$ NMR (DMSO-d $\left.\mathrm{d}_{6}\right) \delta 0.91\left(\mathrm{t}, \mathrm{J}=7.0 \mathrm{~Hz}, 3 \mathrm{H}, \mathrm{CH}_{3}\right), 1.31\left(\mathrm{~m}, 18 \mathrm{H}, \mathrm{CH}_{2}\right), 2.39\left(\mathrm{~s}, 4 \mathrm{H}, \mathrm{CH}_{2}\right)$, $3.39\left(\mathrm{~s}, 4 \mathrm{H}, \mathrm{CH}_{2}\right), 6.86(\mathrm{~m}, 1 \mathrm{H}, \mathrm{Ar}), 7.11(\mathrm{~m}, 1 \mathrm{H}, \mathrm{Ar}), 7.27(\mathrm{~m}, 1 \mathrm{H}, \mathrm{Ar}), 7.43\left(\mathrm{~s}, 2 \mathrm{H}, \mathrm{NH}_{2}\right), 8.40(\mathrm{~s}, 1 \mathrm{H}, \mathrm{NH}) .{ }^{13} \mathrm{C}$ NMR (DMSO-d $\mathrm{d}_{6}$ ) $\delta 17.0,22.7,25.22,27.5,28.2,30.4,32.2,34.7(2 \mathrm{C}), 47.1(2 \mathrm{C}), 57.3(2 \mathrm{C}), 62.2,113.4\left(\mathrm{~d},{ }^{2} \mathrm{~J}_{\mathrm{CF}}\right.$ $=23.7 \mathrm{~Hz}), 118.4\left(\mathrm{~d},{ }^{3} \mathrm{~J}_{\mathrm{CF}}=5.4 \mathrm{~Hz}\right), 120.9\left(\mathrm{~d},{ }^{4} \mathrm{~J}_{\mathrm{CF}}=4.4 \mathrm{~Hz}\right), 133.8\left(\mathrm{~d},{ }^{3} \mathrm{~J}_{\mathrm{CF}}=9.5 \mathrm{~Hz}\right), 143.2\left(\mathrm{~d},{ }^{2} \mathrm{~J}_{\mathrm{CF}}=16.2 \mathrm{~Hz}\right), 155.4$ $\left(d,{ }^{1} J_{C F}=232.0 \mathrm{~Hz}\right.$ ), 156.1. IR (Nujol) 3366, 1644, $1519 \mathrm{~cm}^{-1} . \mathrm{m} / \mathrm{z} 459(\mathrm{M}+\mathrm{H})^{+}$. Anal. Calcd. for $\mathrm{C}_{21} \mathrm{H}_{35} \mathrm{FN}_{4} \mathrm{O}_{4} \mathrm{~S}$ (458.59) C, 55.00; H, 7.69; N, 12.22. Found C, 54.93; H, 7.71; N, 12.26.

\subsubsection{2-Chloro-4-(4-(4-chlorophenyl)piperazine-1-carboxamido)phenyl sulfamate (22)}

Following the general procedure, the title compound was prepared starting from 4-chlorophenylpiperazine. Yield 82\%. M.p. 84-85 ${ }^{\circ} \mathrm{C} .{ }^{1} \mathrm{H}$ NMR (DMSO-d 6 ) $\delta 3.16\left(\mathrm{~s}, 4 \mathrm{H}, \mathrm{CH}_{2}\right.$ ), $3.57\left(\mathrm{~s}, 4 \mathrm{H}, \mathrm{CH}_{2}\right), 6.86(\mathrm{~d}, \mathrm{~J}=8.0 \mathrm{~Hz}, 2 \mathrm{H}, \mathrm{Ar}$ ), $7.19(\mathrm{~m}, 3 \mathrm{H}, \mathrm{Ar}), 7.25(\mathrm{~m}, 2 \mathrm{H}, \mathrm{Ar}), 7.51$ (s, 2H, NH$\left.)_{2}\right), 8.47(\mathrm{~s}, 1 \mathrm{H}, \mathrm{NH}) .{ }^{13} \mathrm{C}$ NMR (DMSO-d $) \delta 52.4(2 \mathrm{C}), 54.2$ (2C), 116.2 (2C), 117.2, 120.9, 123.0, 124.7, 128.8, 130.2 (2C), 133.5, 148.0, 152.6, 158.0 IR (Nujol) 3279, $1638,1594 \mathrm{~cm}^{-1} . \mathrm{m} / \mathrm{z} 446(\mathrm{M}+\mathrm{H})^{+}$. Anal. Calcd. for $\mathrm{C}_{17} \mathrm{H}_{18} \mathrm{Cl}_{2} \mathrm{~N}_{4} \mathrm{O}_{4} \mathrm{~S}(445.32) \mathrm{C}, 45.85 ; \mathrm{H}, 4.07 ; \mathrm{N}, 12.58$. Found C, $45.89 ; \mathrm{H}, 4.09 ; \mathrm{N} 12.61$.

\subsubsection{2-Chloro-4-(4-(2,3-dimethylphenyl)piperazine-1-carboxamido)phenyl sulfamate (23)}

Following the general procedure, the title compound was prepared starting from 2,3dimethylphenylpiperazine. Yield 60\%. M.p. 89-90 ${ }^{\circ} \mathrm{C} .{ }^{1} \mathrm{H}$ NMR (DMSO- $\left.\mathrm{d}_{6}\right) \delta 2.17\left(\mathrm{~s}, 3 \mathrm{H}, \mathrm{CH}_{3}\right), 2.20\left(\mathrm{~s}, 3 \mathrm{H}, \mathrm{CH}_{3}\right)$, $2.80\left(\mathrm{~s}, 4 \mathrm{H}, \mathrm{CH}_{2}\right), 3.58\left(\mathrm{~s}, 4 \mathrm{H}, \mathrm{CH}_{2}\right), 6.88(\mathrm{~m}, 2 \mathrm{H}, \mathrm{Ar}), 7.06(\mathrm{~m}, 2 \mathrm{H}, \mathrm{Ar}), 7.21(\mathrm{~m}, 2 \mathrm{H}, \mathrm{Ar}), 7.52\left(\mathrm{~s}, 2 \mathrm{H}, \mathrm{NH}_{2}\right), 8.44$ $(\mathrm{s}, 1 \mathrm{H}, \mathrm{NH}) .{ }^{13} \mathrm{C}$ NMR (DMSO-d 6 ) $\delta 16.8,23.4,47.4,(2 \mathrm{C}), 55.0$ (2C), 119.8, 123.6 (2C), 125.3 (2C), 128.0, 128.9, $130.7,140.5,142.1,147.7,154.2,158.2$. IR (Nujol) 3321, 1638, $1592 \mathrm{~cm}^{-1} . \mathrm{m} / \mathrm{z} 439(\mathrm{M}+\mathrm{H})^{+}$. Anal. Calcd. for $\mathrm{C}_{19} \mathrm{H}_{23} \mathrm{ClN}_{4} \mathrm{O}_{4} \mathrm{~S}$ (438.93) C, 51.99; $\mathrm{H}, 5.28 ; \mathrm{N}, 12.76$. Found $\mathrm{C}, 52.05 ; \mathrm{H}, 5.26 ; \mathrm{N}, 12.79$.

\subsubsection{2-Chloro-4-(4-octylpiperazine-1-carboxamido)phenyl sulfamate (24)}

Following the general procedure, the title compound was prepared starting from $n$-octylpiperazine. Yield 18\%. M.p. $108-110^{\circ} \mathrm{C} .{ }^{1} \mathrm{H}$ NMR (DMSO-d 6 ) $\delta 0.88\left(\mathrm{~m}, 3 \mathrm{H}, \mathrm{CH}_{3}\right), 1.29\left(\mathrm{~m}, 14 \mathrm{H}, \mathrm{CH}_{2}\right), 2.34\left(\mathrm{~s}, 4 \mathrm{H}, \mathrm{CH}_{2}\right), 3.46(\mathrm{~s}$, $\left.4 \mathrm{H}, \mathrm{CH}_{2}\right), 7.17(\mathrm{~d}, \mathrm{~J}=7 \mathrm{~Hz}, 1 \mathrm{H}, \mathrm{Ar}), 7.44(\mathrm{~s}, 1 \mathrm{H}, \mathrm{Ar}), 7.47(\mathrm{~d}, \mathrm{~J}=7.5 \mathrm{~Hz}, 1 \mathrm{H}, \mathrm{Ar}), 7.75\left(\mathrm{~s}, 2 \mathrm{H}, \mathrm{NH}_{2}\right), 8.44(\mathrm{~s}, 1 \mathrm{H}$, $\mathrm{NH}) .{ }^{13} \mathrm{C}$ NMR (DMSO-d 6 ) $\delta$ 15.0, 22.7, 26.2, 28.5, 29.0 (2C), 32.7, 53.1 (2C), $58.3(2 \mathrm{C}), 61.8,119.4,122.2$, 123.6, 125.8, 130.7, 154.2, 155.5. IR (Nujol) 3346, 1641, $1595 \mathrm{~cm}^{-1} . \mathrm{m} / \mathrm{z} 447(\mathrm{M}+\mathrm{H})^{+}$. Anal. Calcd. for $\mathrm{C}_{19} \mathrm{H}_{31} \mathrm{ClN}_{4} \mathrm{O}_{4} \mathrm{~S}$ (446.99) $\mathrm{C}, 51.05 ; \mathrm{H}, 6.99 ; \mathrm{N}, 12.53$. Found $\mathrm{C}, 51.12 ; \mathrm{H}, 7.02 ; \mathrm{N}, 12.57$. 
4.2.4.13. 2-Chloro-4-(4-decy/piperazine-1-carboxamido)phenyl sulfamate (25)

Following the general procedure, the title compound was prepared starting from $n$-decylpiperazine. Yield 70\%. M.p. 92-93 ${ }^{\circ} \mathrm{C} .{ }^{1} \mathrm{H}$ NMR (DMSO- $\left.\mathrm{d}_{6}\right) \delta 0.87\left(\mathrm{~m}, 3 \mathrm{H}, \mathrm{CH}_{3}\right), 1.27\left(\mathrm{~m}, 18 \mathrm{H}, \mathrm{CH}_{2}\right), 2.36\left(\mathrm{~s}, 4 \mathrm{H}, \mathrm{CH}_{2}\right), 3.46(\mathrm{~s}, 4 \mathrm{H}$, $\left.\mathrm{CH}_{2}\right), 7.11(\mathrm{~d}, \mathrm{~J}=9.0 \mathrm{~Hz}, 1 \mathrm{H}, \mathrm{Ar}), 7.46(\mathrm{~d}, \mathrm{~J}=9.0 \mathrm{~Hz}, 1 \mathrm{H}, \mathrm{Ar}), 7.53(\mathrm{~m}, 1 \mathrm{H}, \mathrm{Ar}), 7.61\left(\mathrm{~s}, 2 \mathrm{H}, \mathrm{NH}_{2}\right), 9.36(\mathrm{~s}, 1 \mathrm{H}$, NH). ${ }^{13}$ C NMR (DMSO-d $d_{6}$ ) $16.8,25.2,31.7$ (2C), 31.9 (2C), 32.0, 33.1 (2C), 53.1 (2C), $57.6(2 \mathrm{C}), 60.2,119.2$, 120.8, 122.4, 124.8, 131.3, 155.0, 157.4. IR (Nujol) 3348, 1633, $1596 \mathrm{~cm}^{-1} . \mathrm{m} / \mathrm{z} 475(\mathrm{M}+\mathrm{H})^{+}$. Anal. Calcd. for $\mathrm{C}_{21} \mathrm{H}_{35} \mathrm{ClN}_{4} \mathrm{O}_{4} \mathrm{~S}(474.04) \mathrm{C}, 53.09 ; \mathrm{H}, 7.43 ; \mathrm{N} 11.79$. Found $\mathrm{C}, 53.16 ; \mathrm{H}, 7.45 ; \mathrm{N}, 11.76$.

4.2.4.14. 4-(4-(4-Chlorophenyl)piperazine-1-carboxamido)-3-fluorophenyl sulfamate (26)

Following the general procedure, the title compound was prepared starting from 4-chlorophenylpiperazine. Yield 20\%. M.p. 94-95 ${ }^{\circ}$ C. ${ }^{1} \mathrm{H}$ NMR (DMSO-d $\left.\mathrm{d}_{6}\right) \delta 3.16\left(\mathrm{~s}, 4 \mathrm{H}, \mathrm{CH}_{2}\right), 3.55\left(\mathrm{~s}, 4 \mathrm{H}, \mathrm{CH}_{2}\right), 6.55(\mathrm{~m}, 1 \mathrm{H}, \mathrm{Ar}), 6.91(\mathrm{~m}$, $1 \mathrm{H}, \operatorname{Ar}$ ), $7.00(\mathrm{~d}, \mathrm{~J}=8.0 \mathrm{~Hz}, 2 \mathrm{H}, \mathrm{Ar}), 7.11(\mathrm{~m}, 1 \mathrm{H}, \mathrm{Ar}), 7.25$ (d, J = 8.0 Hz, 2H, Ar), $8.10\left(\mathrm{~s}, 2 \mathrm{H}, \mathrm{NH}_{2}\right), 8.87(\mathrm{~s}, 1 \mathrm{H}$, $\mathrm{NH}) .{ }^{13} \mathrm{C}$ NMR (DMSO-d $) \delta 45.3(2 \mathrm{C}), 49.4(2 \mathrm{C}), 109.4\left(\mathrm{~d},{ }^{2} \mathrm{~J}_{\mathrm{CF}}=13.6 \mathrm{~Hz}\right), 115.8\left(\mathrm{~d},{ }^{3} \mathrm{~J}_{\mathrm{CF}}=7.1 \mathrm{~Hz}\right), 117.2\left(\mathrm{~d},{ }^{4} \mathrm{~J}_{\mathrm{CF}}\right.$ $=3.6 \mathrm{~Hz}), 121.3(2 \mathrm{C}), 125.0\left(\mathrm{~d},{ }^{3} \mathrm{~J}_{\mathrm{CF}}=8.6 \mathrm{~Hz}\right), 127.6,130.8(2 \mathrm{C}), 142.8\left(\mathrm{~d},{ }^{3} \mathrm{~J}_{\mathrm{CF}}=9.5 \mathrm{~Hz}\right), 145.8,153.9\left(\mathrm{~d},{ }^{1} \mathrm{~J}_{\mathrm{CF}}=\right.$ $244.5 \mathrm{~Hz}$ ), 163.0. IR (Nujol) 3431, 3165, 1645, 1627, $1597 \mathrm{~cm}^{-1} . \mathrm{m} / \mathrm{z} 429(\mathrm{M}+\mathrm{H})^{+}$. Anal. Calcd. for $\mathrm{C}_{17} \mathrm{H}_{18} \mathrm{ClFN}_{4} \mathrm{O}_{4} \mathrm{~S}$ (428.87) C, 47.61; $\mathrm{H}, 4.23 ; \mathrm{N}, 13.06$. Found $\mathrm{C}, 47.66 ; \mathrm{H}, 4.21 ; \mathrm{N}, 13.10$.

\subsubsection{4-(4-(2,3-Dimethylphenyl)piperazine-1-carboxamido)-3-fluorophenyl sulfamate (27)}

Following the general procedure, the title compound was prepared starting from 2,3dimethylphenylpiperazine. Yield 58\%. M.p. $87-88^{\circ} \mathrm{C} .{ }^{1} \mathrm{H}$ NMR (DMSO-d $)$ $\delta 2.21\left(\mathrm{~s}, 3 \mathrm{H}, \mathrm{CH}_{3}\right), 2.23\left(\mathrm{~s}, 3 \mathrm{H}, \mathrm{CH}_{3}\right)$, $2.70\left(\mathrm{~s}, 2 \mathrm{H}, \mathrm{CH}_{2}\right), 2.87\left(\mathrm{~s}, 2 \mathrm{H}, \mathrm{CH}_{2}\right), 3.57\left(\mathrm{~s}, 4 \mathrm{H}, \mathrm{CH}_{2}\right), 6.57(\mathrm{~m}, 2 \mathrm{H}, \mathrm{Ar}), 6.91(\mathrm{~m}, 3 \mathrm{H}, \mathrm{Ar}), 7.11(\mathrm{~m}, 1 \mathrm{H}, \mathrm{Ar}), 8.07$

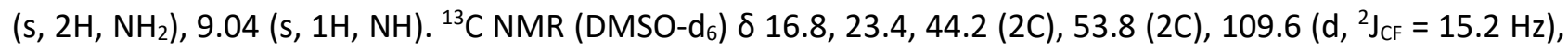
$112.1,115.7\left(\mathrm{~d},{ }^{3} \mathrm{~J}_{\mathrm{CF}}=8.1 \mathrm{~Hz}\right), 117.0\left(\mathrm{~d},{ }^{4} \mathrm{~J}_{\mathrm{CF}}=3.5 \mathrm{~Hz}\right), 121.2,122.1,124.9\left(\mathrm{~d},{ }^{3} \mathrm{~J}_{\mathrm{CF}}=8.4 \mathrm{~Hz}\right), 129.3,140.2,142.7$ $\left(d,{ }^{3} \mathrm{JF}_{\mathrm{CF}}=9.0 \mathrm{~Hz}\right), 149.4,154.3\left(\mathrm{~d},{ }^{1} \mathrm{JCF}=243.6 \mathrm{~Hz}\right), 159.9 . \mathrm{IR}$ (Nujol) $3280,1625,1590 \mathrm{~cm}^{-1} \cdot \mathrm{m} / \mathrm{z} 423(\mathrm{M}+\mathrm{H})^{+}$. Anal. Calcd. for $\mathrm{C}_{19} \mathrm{H}_{23} \mathrm{FN}_{4} \mathrm{O}_{4} \mathrm{~S}(422.47) \mathrm{C}, 54.02 ; \mathrm{H}, 5.49 ; \mathrm{N}, 13.26$. Found $\mathrm{C}, 54.08 ; \mathrm{H}, 5.47 ; \mathrm{N}, 13.22$.

\subsubsection{3-Fluoro-4-(4-octylpiperazine-1-carboxamido)phenyl sulfamate (28)}

Following the general procedure, the title compound was prepared starting from $n$-octylpiperazine. Yield 11\%. M.p. 78-79 ${ }^{\circ} \mathrm{C} .{ }^{1} \mathrm{H}$ NMR (DMSO- $\left.\mathrm{d}_{6}\right) \delta 0.87\left(\mathrm{~m}, 3 \mathrm{H}, \mathrm{CH}_{3}\right), 1.28\left(\mathrm{~m}, 14 \mathrm{H}, \mathrm{CH}_{2}\right), 2.45\left(\mathrm{~s}, 4 \mathrm{H}, \mathrm{CH}_{2}\right), 3.38(\mathrm{~s}, 4 \mathrm{H}$, $\left.\mathrm{CH}_{2}\right), 7.22(\mathrm{~d}, \mathrm{~J}=7.0 \mathrm{~Hz}, 1 \mathrm{H}, \mathrm{Ar}), 7.51(\mathrm{~s}, 1 \mathrm{H}, \mathrm{Ar}), 7.59(\mathrm{~d}, \mathrm{~J}=7.5 \mathrm{~Hz}, 1 \mathrm{H}, \mathrm{Ar}), 7.73\left(\mathrm{~s}, 2 \mathrm{H}, \mathrm{NH}_{2}\right), 8.51(\mathrm{~s}, 1 \mathrm{H}, \mathrm{NH})$. ${ }^{13} \mathrm{C}$ NMR (DMSO- $\left.\mathrm{d}_{6}\right) \delta 17.1,25.1,28.7,29.9,31.8,34.0(2 \mathrm{C}), 46.8(2 \mathrm{C}), 55.5(2 \mathrm{C}), 60.7,109.2\left(\mathrm{~d},{ }^{2} \mathrm{~J}_{\mathrm{CF}}=12.8\right.$ $\mathrm{Hz}), 116.0\left(\mathrm{~d},{ }^{3} \mathrm{~J}_{\mathrm{CF}}=8.4 \mathrm{~Hz}\right), 117.3\left(\mathrm{~d}, \mathrm{~J}_{\mathrm{CF}}=3.6 \mathrm{~Hz}\right), 125.0\left(\mathrm{~d},{ }^{3} \mathrm{~J}_{\mathrm{CF}}=8.6 \mathrm{~Hz}\right), 142.4\left(\mathrm{~d},{ }^{3} \mathrm{~J}_{\mathrm{CF}}=8.4 \mathrm{~Hz}\right), 155.0(\mathrm{~d}$, ${ }^{1} \mathrm{JCF}=247.0 \mathrm{~Hz}$ ), 161.2. IR (Nujol) 3430, 1644, $1596 \mathrm{~cm}^{-1} . \mathrm{m} / \mathrm{z} 431(\mathrm{M}+\mathrm{H})^{+}$. Anal. Calcd. for $\mathrm{C}_{19} \mathrm{H}_{31} \mathrm{FN}_{4} \mathrm{O}_{4} \mathrm{~S}$ (430.54) C, 53.00; H, 7.26; N 13.01. Found C, 52.94; H, 7.29; N 13.05.

\subsubsection{4-(4-Decylpiperazine-1-carboxamido)-3-fluorophenyl sulfamate (29)}

Following the general procedure, the title compound was prepared starting from $n$-decylpiperazine. Yield 12\%. M.p. 81-82 ${ }^{\circ} \mathrm{C} .{ }^{1} \mathrm{H}$ NMR (DMSO-d $\left.\mathrm{d}_{6}\right) \delta 0.92\left(\mathrm{~m}, 3 \mathrm{H}, \mathrm{CH}_{3}\right), 1.95\left(\mathrm{~m}, 18 \mathrm{H}, \mathrm{CH}_{2}\right), 2.17\left(\mathrm{~s}, 4 \mathrm{H}, \mathrm{CH}_{2}\right), 3.39(\mathrm{~s}, 4 \mathrm{H}$, $\left.\mathrm{CH}_{2}\right), 7.15(\mathrm{~m}, 1 \mathrm{H}, \mathrm{Ar}), 7.44(\mathrm{~m}, 1 \mathrm{H}, \mathrm{Ar}), 7.77(\mathrm{~m}, 1 \mathrm{H}, \mathrm{Ar}), 7.80\left(\mathrm{~s}, 2 \mathrm{H}, \mathrm{NH}_{2}\right), 8.49(\mathrm{~s}, 1 \mathrm{H}, \mathrm{NH}) .{ }^{13} \mathrm{C}$ NMR (DMSO- 
$\left.d_{6}\right) \delta 16.8,25.2,31.7(2 \mathrm{C}), 31.9(2 \mathrm{C}), 32.0,33.1(2 \mathrm{C}), 53.1(2 \mathrm{C}), 57.6(2 \mathrm{C}), 60.2,109.3\left(\mathrm{~d},{ }^{2} \mathrm{~J}_{\mathrm{CF}}=12.7 \mathrm{~Hz}\right), 115.9$ $\left(d,{ }^{3} \mathrm{JF}_{\mathrm{CF}}=8.5 \mathrm{~Hz}\right), 117.5\left(\mathrm{~d},{ }^{4} \mathrm{~J}_{\mathrm{CF}}=3.5 \mathrm{~Hz}\right), 124.8\left(\mathrm{~d},{ }^{3} \mathrm{~J}_{\mathrm{CF}}=8.7 \mathrm{~Hz}\right), 142.2\left(\mathrm{~d},{ }^{3} \mathrm{~J}_{\mathrm{CF}}=8.5 \mathrm{~Hz}\right), 155.6\left(\mathrm{~d},{ }^{1} \mathrm{JCF}=242.3\right.$ $\mathrm{Hz}$ ), $159.1 \mathrm{IR}$ (Nujol) 3346, 1644, $1614 \mathrm{~cm}^{-1} . \mathrm{m} / \mathrm{z} 459(\mathrm{M}+\mathrm{H})^{+}$. Anal. Calcd. for $\mathrm{C}_{21} \mathrm{H}_{35} \mathrm{FN}_{4} \mathrm{O}_{4} \mathrm{~S}$ (458.59) C, 55.00; $H, 7.69 ; N$ 12.22. Found C, 55.06; H, 7.66; N, 12.26 .

\subsubsection{3-Chloro-4-(4-octylpiperazine-1-carboxamido)phenyl sulfamate (30)}

Following the general procedure, the title compound was prepared starting from $n$-octylpiperazine. Yield 38\%. M.p. 106-107 ${ }^{\circ} \mathrm{C} .{ }^{1} \mathrm{H}$ NMR (DMSO- $\left.\mathrm{d}_{6}\right) \delta 0.93\left(\mathrm{~m}, 3 \mathrm{H}, \mathrm{CH}_{3}\right), 1.04\left(\mathrm{~m}, 14 \mathrm{H}, \mathrm{CH}_{2}\right), 2.18\left(\mathrm{~s}, 4 \mathrm{H}, \mathrm{CH}_{2}\right), 3.65(\mathrm{~s}$, $\left.4 \mathrm{H}, \mathrm{CH}_{2}\right), 7.24(\mathrm{~m}, 1 \mathrm{H}, \mathrm{Ar}), 7.60(\mathrm{~m}, 2 \mathrm{H}, \mathrm{Ar}), 7.90\left(\mathrm{~s}, 2 \mathrm{H}, \mathrm{NH}_{2}\right), 8.78(\mathrm{~s}, 1 \mathrm{H}, \mathrm{NH}) .{ }^{13} \mathrm{C}$ NMR (DMSO-d 6 ) $\delta 17.0$, 25.2, 29.7, 31.8, 31.9, 34.4 (2C), 45.9 (2C), 55.2 (2C), 60.3, 119.3, 121.9, 123.1, 124.6, 135.8, 151.2, 157.9. IR (Nujol) 3324, 1636, $1603 \mathrm{~cm}^{-1}$. m/z $447(\mathrm{M}+\mathrm{H})^{+}$. Anal. Calcd. for $\mathrm{C}_{19} \mathrm{H}_{31} \mathrm{ClN}_{4} \mathrm{O}_{4} \mathrm{~S}$ (446.99) C, 51.05; H, 6.99; N, 12.53. Found C, 51.11; H, 6.96; N, 12.57.

\subsubsection{3-Chloro-4-(4-decylpiperazine-1-carboxamido)phenyl sulfamate (31)}

Following the general procedure, the title compound was prepared starting from $n$-decylpiperazine. Yield 35\%. M.p. 57-58 ${ }^{\circ} \mathrm{C} .{ }^{1} \mathrm{H}$ NMR (DMSO- $\left.\mathrm{d}_{6}\right) \delta 0.95\left(\mathrm{~m}, 3 \mathrm{H}, \mathrm{CH}_{3}\right), 1.95\left(\mathrm{~m}, 16 \mathrm{H}, \mathrm{CH}_{2}\right), 2.11\left(\mathrm{~s}, 2 \mathrm{H}, \mathrm{CH}_{2}\right), 3.46(\mathrm{~s}, 4 \mathrm{H}$, $\left.\mathrm{CH}_{2}\right), 3.88\left(\mathrm{~s}, 2 \mathrm{H}, \mathrm{CH}_{2}\right), 4.10\left(\mathrm{~s}, 2 \mathrm{H}, \mathrm{CH}_{2}\right), 7.26(\mathrm{~m}, 1 \mathrm{H}, \mathrm{Ar}), 7.40(\mathrm{~m}, 1 \mathrm{H}, \mathrm{Ar}), 7.70(\mathrm{~m}, 1 \mathrm{H}, \mathrm{Ar}), 7.89\left(\mathrm{~s}, 2 \mathrm{H}, \mathrm{NH}_{2}\right)$, $8.88(\mathrm{~s}, 1 \mathrm{H}, \mathrm{NH}) .{ }^{13} \mathrm{C}$ NMR (DMSO-d $\left.\mathrm{d}_{6}\right) \delta 16.8,25.2,31.7(2 \mathrm{C}), 31.9(2 \mathrm{C}), 32.0,33.1(2 \mathrm{C}), 53.1(2 \mathrm{C}), 57.6(2 \mathrm{C})$, 60.2, 119.7, 120.9, 122.2, 124.2, 131.6, 155.4, 157.0. IR (Nujol) 3307, 1639, $1608 \mathrm{~cm}^{-1} . \mathrm{m} / \mathrm{z} 476(\mathrm{M}+\mathrm{H})^{+}$. Anal. Calcd. for $\mathrm{C}_{21} \mathrm{H}_{35} \mathrm{ClN}_{4} \mathrm{O}_{4} \mathrm{~S}(475.04)$ C, 53.09; $\mathrm{H}, 7.43 ; \mathrm{N}, 11.79$. Found C, 53.14; $\mathrm{H}, 7.45 ; \mathrm{N}, 11.75$.

\subsection{5. (E)-3-(Dimethylamino)-1-(3,4-dimethoxyphenyl)prop-2-en-1-one (33f)}

A mixture of 3,4-dimethoxyacetophenone $(0.9 \mathrm{~g}, 5 \mathrm{mmol})$ and DMF-DMA $(1.79 \mathrm{~g}, 15 \mathrm{mmol})$ in anhydrous toluene $(10 \mathrm{~mL})$ was refluxed for $1 \mathrm{~h}$, then was allowed to reach the room temperature and stirred for additional $24 \mathrm{~h}$. The mixture was carefully concentrated in vacuum to the title compound in $77 \%$ yield. M.p. 113-114 ${ }^{\circ} \mathrm{C}$ (n-hexane). ${ }^{1} \mathrm{H}$ NMR (DMSO-d $\left.\mathrm{d}_{6}\right) \delta 2.91\left(\mathrm{~s}, 3 \mathrm{H}, \mathrm{CH}_{3}\right), 3.12\left(\mathrm{~s}, 3 \mathrm{H}, \mathrm{CH}_{3}\right), 3.81\left(\mathrm{~s}, 6 \mathrm{H}, \mathrm{OCH}_{3}\right), 5.81(\mathrm{~d}, \mathrm{~J}$ $=12.0 \mathrm{~Hz}, 1 \mathrm{H}, \mathrm{CH}), 6.97(\mathrm{~d}, \mathrm{~J}=8.0 \mathrm{~Hz}, 1 \mathrm{H}, \mathrm{Ar}), 7.45(\mathrm{~s}, 1 \mathrm{H}, \operatorname{Ar}), 7.53(\mathrm{~d}, \mathrm{~J}=8.5 \mathrm{~Hz}, 1 \mathrm{H}, \operatorname{Ar}), 7.65(\mathrm{~d}, \mathrm{~J}=12.0 \mathrm{~Hz}$, $1 \mathrm{H}, \mathrm{CH}$ ). IR (Nujol) 3583, $1636 \mathrm{~cm}^{-1} . \mathrm{m} / \mathrm{z} 254(\mathrm{M}+\mathrm{H})^{+}$. Anal. Calcd. for $\mathrm{C}_{13} \mathrm{H}_{17} \mathrm{NO}_{3}$ (253.28) C, 66.36; H, 7.28; N, 5.95. Found C, 66.27; H, 7.31; N, 5.93.

\subsubsection{4-(3,4-Dimethoxyphenyl)-2-(piperazin-1-yl)pyrimidine (34f)}

A solution of (E)-3-(dimethylamino)-1-(3,4-dimethoxyphenyl)prop-2-en-1-one (0.51 g, 2 mmol), 4-(tertbutoxycarbonyl)piperazine-1-carboxamidine (1.02 g, $2.2 \mathrm{mmol}$ ) and sodium methylate $30 \% \mathrm{MeOH}$ solution $(0.8 \mathrm{ml}, 4 \mathrm{mmol})$ in anhydrous $\mathrm{EtOH}(5 \mathrm{~mL})$ was refluxed $8 \mathrm{~h}$. After cooling to room temperature the solvent was removed under reduced pressure. The residue was treated with ethyl acetate $(20 \mathrm{~mL})$ and washed with water $(3 \times 10 \mathrm{~mL})$ and brine $(10 \mathrm{~mL})$. After drying over sodium sulphate the solvent was removed under reduced pressure. Then the residue was solubilised in anhydrous dichloromethane $(10 \mathrm{~mL})$ and trifluoroacetic acid $(5 \mathrm{~mL}$ ) was added. The mixture was stirred at room temperature overnight and after evaporation of the solvent, the residue was treated with a diethyl ether $(20 \mathrm{~mL})$ to obtain a solid that was filtered off and dried. 
The formed solid was used in the next step without further purification. Yield $48 \%$. M.p. $>240^{\circ} \mathrm{C} .{ }^{1} \mathrm{H}$ NMR (DMSO-d 6 ) $\delta 1.91(\mathrm{~s}, 1 \mathrm{H}, \mathrm{NH}), 2.79\left(\mathrm{~s}, 4 \mathrm{H}, \mathrm{CH}_{2}\right), 3.33\left(\mathrm{~s}, 4 \mathrm{H}, \mathrm{CH}_{2}\right), 4.31\left(\mathrm{~s}, 6 \mathrm{H}, \mathrm{OCH}_{3}\right), 6.97(\mathrm{~d}, \mathrm{~J}=7.0 \mathrm{~Hz}, 1 \mathrm{H}$, Ar), $7.25\left(\mathrm{~s}, 1 \mathrm{H}, \mathrm{Ar}\right.$ ), 7.54 (d, J = $7.5 \mathrm{~Hz}, 1 \mathrm{H}, \mathrm{Ar}$ ), 7.85 (m, 2H, Ar). IR (Nujol) 3583, $1636 \mathrm{~cm}^{-1} . \mathrm{m} / \mathrm{z} 301(\mathrm{M}+\mathrm{H})^{+}$. Anal. Calcd. for $\mathrm{C}_{16} \mathrm{H}_{20} \mathrm{~N}_{4} \mathrm{O}_{2}(300.36) \mathrm{C}, 63.98 ; \mathrm{H}, 6.71 ; \mathrm{N}, 18.65$. Found $\mathrm{C}, 63.87 ; \mathrm{H}, 6.74 ; \mathrm{N}, 18.70$.

4.2.7. General procedure for the synthesis of 4-(4-(4-aryl)pyrimidin-2-yl)piperazinocarbonyl)aminophenyl sulfamates (35-42)

A mixture of 4-(phenoxycarbonyl)aminophenylsulfamate $(0,31 \mathrm{~g}, 1 \mathrm{mmol})$ and pyrimidines $34 \mathrm{a}-\mathrm{h}(1 \mathrm{mmol})$, in anhydrous DMSO (3 mL) was stirred at room temperature for $24 \mathrm{~h}$. Then, water $(10 \mathrm{~mL})$ was added and the mixture was stirred at room temperature until a solid is formed. The formed solid was filtered off, washed with water, air dried and recrystallized from EtOH to give ureas 35-42.

4.2.7.1. 4-(4-(4-(3,4-Dimethoxyphenyl)pyrimidin-2-yl)piperazine-1-carboxamido)phenyl sulfamate (40)

Following the general procedure, the title compound was obtained in $27 \%$ yield. Oil. ${ }^{1} \mathrm{H}$ NMR (DMSO-d 6 $3.56\left(\mathrm{~s}, 4 \mathrm{H}, \mathrm{CH}_{2}\right), 3.83\left(\mathrm{~s}, 4 \mathrm{H}, \mathrm{CH}_{2}\right), 4.42\left(\mathrm{~s}, 6 \mathrm{H}, \mathrm{CH}_{2}\right), 7.07(\mathrm{~m}, 2 \mathrm{H}, \mathrm{Ar}), 7.19(\mathrm{~s}, 1 \mathrm{H}, \mathrm{Ar}), 7.45(\mathrm{~d}, \mathrm{~J}=7.5 \mathrm{~Hz}, 1 \mathrm{H}$, $\operatorname{Ar}), 7.56(\mathrm{~d}, \mathrm{~J}=8.0 \mathrm{~Hz}, 2 \mathrm{H}, \mathrm{Ar}), 7.77\left(\mathrm{~d}, \mathrm{~J}=7.0 \mathrm{~Hz}, 1 \mathrm{H}, \mathrm{Ar}\right.$ ), $7.84(\mathrm{~s}, 1 \mathrm{H}, \mathrm{NH}), 8.33\left(\mathrm{~s}, 2 \mathrm{H}, \mathrm{NH}_{2}\right), 8.61$ (d, J = 8.5 $\mathrm{Hz}, 2 \mathrm{H}, \mathrm{Ar}$ ). ${ }^{13} \mathrm{C}$ NMR (DMSO-d 6 ) $\delta 51.1$ (2C), 52.0 (2C), 57.2 (2C), 105.3, 108.6, 110.8, 121.3 (2C), 122.0, 123.3 (2C), 130.3, 133.6, 148.1, 150.3 (2C), 154.2, 155.5, 163.5, 166.7. IR (Nujol) 3328, 1634, $1516 \mathrm{~cm}^{-1} . \mathrm{m} / \mathrm{z} 515$ (M $+\mathrm{H})^{+}$. Anal. Calcd. for $\mathrm{C}_{23} \mathrm{H}_{26} \mathrm{~N}_{6} \mathrm{O}_{6} \mathrm{~S}(514.55) \mathrm{C}, 53.69 ; \mathrm{H}, 5.09 ; \mathrm{N}, 16.33$. Found $\mathrm{C}, 53.62 ; \mathrm{H}, 5.11 ; \mathrm{N}, 16.37$.

\subsection{STS assay}

STS inhibitory assays were performed as described previously [19]. Briefly, the ability of a compound to inhibit STS activity was determined using the lysate of JEG-3, a human placenta choriocarcinoma cell line known to have high STS activity. To determine STS inhibition, activity was measured in the absence and presence of the inhibitor $(0.001-10 \mu \mathrm{M})$ using $\left[{ }^{3} \mathrm{H}\right] \mathrm{E}_{1} \mathrm{~S}\left(4 \times 10^{5} \mathrm{dpm}\right.$, Perkin Elmer) adjusted to $20 \mu \mathrm{M}$ with unlabelled $\mathrm{E}_{1} \mathrm{~S}$ substrate. After incubation of the substrate-inhibitor with JEG-3 lysate (125 $\mu \mathrm{g}$ of protein/mL) for $1 \mathrm{~h}$, the product formed estrone $\left(E_{1}\right)$ was separated from the mixture by extraction with toluene $(4 \mathrm{~mL})$. [4- $\left.{ }^{14} \mathrm{C}\right] \mathrm{E}_{1}$ (American Radiolabelled Chemicals) was also used throughout the assay to monitor procedural losses.

To ascertain whether compounds were able to pass through the cell lipid bilayer, intact monolayers of JEG-3 cells were incubated for $20 \mathrm{~h}$ at $37{ }^{\circ} \mathrm{C}$ with $\left[{ }^{3} \mathrm{H}\right] \mathrm{E}_{1} \mathrm{~S}\left(5 \mathrm{pmol}, 7 \times 10^{5} \mathrm{dpm}, 60 \mathrm{Ci} / \mathrm{mmol}\right)$ in serum-free Eagle's Minimal Essential Medium $(1.0 \mathrm{~mL})$ with or without inhibitors $(10 \mu \mathrm{M})$. After incubation, medium $(0.5 \mathrm{~mL})$ was removed and product $E_{1}$ separated from $E_{1} S$ by solvent partition using toluene $(4 \mathrm{~mL})$. $\left[{ }^{14} \mathrm{C}\right]$ Estrone $\left(7 \times 10^{3} \mathrm{dpm}, 52 \mathrm{mCi} / \mathrm{mmol}\right)$ was used to correct for procedural losses. An organic phase aliquot was added to scintillation fluid and the ${ }^{3} \mathrm{H}$ and ${ }^{14} \mathrm{C}$ content measured by scintillation spectrometry. The mass of $E_{1} S$ hydrolyzed was calculated from the ${ }^{3} \mathrm{H}$ counts detected (corrected for the volume of medium and organic solvent used and for recovery of ${ }^{14} \mathrm{C}$ counts) and the specific activity of the substrate. 


\section{Acknowledgment}

This work was supported partially by the University of Cagliari FIR funds to GB and VO.

\section{References}

[1] T. Saha, S. Makar, R. Swetha, G. Gutti, S. K. Singh, Estrogen signaling: An emanating therapeutic target for breast cancer treatment, Eur. J. Med. Chem. 177 (2019) 116-143.

[2] S. Stanway, A. Purohit, L. W. L. Woo, S. Sufi, D. Vigushin, R. Ward, R. Wilson, F. Z. Stanczyk, N. Dobbs, E. Kulinskaya, M. Elliott, B. V. L. Potter, M. J. Reed, R. C. Coombes Phase I study of STX64 (667 Coumate) in breast cancer patients: the first study of a steroid sulphatase inhibitor, Clin. Cancer Res. 12 (2006) 15851592.

[3] M.J. Reed, A. Purohit, L.W.L. Woo, S.P. Newman, B.V.L. Potter, Steroid sulfatase: molecular biology, regulation and inhibition, Endocr. Rev. 26 (2005) 171-202.

[4] P.A. Foster, S.P. Newman, S.K. Chander, C. Stengel, R. Jhalli, L. W. L. Woo, B. V. L. Potter, M.J Reed, A. Purohit, A Second-Generation Steroid Sulfatase Inhibitor, for Hormone-Dependent Breast Cancer Therapy, Clin. Cancer Res. 12 (2006) 5543-5549.

[5] R. Shah, J. Singh, D. Singh, A. S. Jaggi, N. Singh, Sulfatase inhibitors for recidivist breast cancer treatment: A chemical review, Eur. J. Med. Chem. 114 (2016) 170-177.

[6] J.W. Mueller, L.C. Gilligan, J. Idkowiak, W. Arlt, P.A. Foster, The Regulation of Steroid Action by Sulfation and Desulfation, Endocr. Rev. 36 (2015) 526-563.

[7] N. M. Howarth, A. Purohit, M, J, Reed, B. V. L. Potter, Estrone sulfamates: potent inhibitors of estrone sulfatase with therapeutic potential J. Med. Chem. 37 (1994) 219-221.

[8] A. Purohit, G. J. Williams, N. M. Howarth, B. V. L. Potter, M. J. Reed, Inactivation of sulfatase by an active site-directed inhibitor, estrone-3-O-sulfamate, Biochemistry 34 (1995) 11508-11514.

[9] M. P. Thomas, B. V. L. Potter, Discovery and Development of the Aryl O-Sulfamate Pharmacophore for Oncology and Women's Health, J. Med. Chem. 58 (2015) 7634-7658.

[10] B. V. L. Potter, Steroid Sulfatase Inhibition by Aryl Sulfamates: Clinical Progress, Mechanism, and Future Prospects, J. Mol. Endocrinol. 61 (2018) 233-252.

[11] S. Colette, S. Defrère, J. C. Lousse , A. Van Langendonckt, J. P. Gotteland, E. Loumaye, J. Donnez, Inhibition of steroid sulfatase decreases endometriosis in an in vivo murine model, Hum. Reprod. 26 (2011) 1362-1370.

[12] O. Pohl, E. Bestel, J. P. Gotteland, Synergistic effects of E2MATE and norethindrone acetate on steroid sulfatase inhibition: a randomized phase I proof-of-principle clinical study in women of reproductive age, Reprod. Sci. 21 (2014) 1256-1265. 
[13] A. Purohit, L. Fusi, J. Brosens, D. Parish, M. S. Fernandes, L. W. L. Woo, B. V. L. Potter, M. J. Reed, Inhibition of steroid sulphatase activity in endometriotic implants by 667 COUMATE: a potential new therapy, Hum. Reprod. 23 (2008) 290-297.

[14] D. Poirier, R. P. Boivin, 17Alpha-alkyl-or 17alpha-substituted benzyl-17beta-estradiols: a new family of estrone-sulfatase inhibitors, Bioorg. Med. Chem. Lett. 8 (1998) 1891-1896.

[15] L. C. Ciobanu, R. P. Boivin, V. Luu-The, F. Labrie, D. Poirier, Potent inhibition of steroid sulfatase activity by 3-O-sulfamate 17alpha-benzyl (or 4'-tert-butylbenzyl) estra-1, 3, 5 (10)-trienes: combination of two substituents at positions C3 and C17 alpha of estradiol, J. Med. Chem. 42 (1999) 2280-2286.

[16] L. W. L. Woo, N. M. Howarth, A. Purohit, H. A. M. Hejaz, M. J. Reed and B. V. L. Potter, Steroidal and nonsteroidal sulfamates as potent inhibitors of steroid sulfatase, J. Med. Chem. 41 (1998) 1068-1083.

[17] L. W. L. Woo, A. Purohit, B. Malini, M. J. Reed, B. V. L. Potter, Potent active site-directed inhibition of steroid sulphatase by tricyclic coumarin-based sulphamates, Chem. Biol. 7 (2000) 773-791.

[18] D. Ganeshapillai, L. W. L. Woo, M. P. Thomas, A. Purohit' B. V. L. Potter, C-3 and C-4 Substituted Bicyclic Coumarin Sulfamates are Potent Steroid Sulfatase Inhibitors, ACS Omega 3 (2018) 10748-10772.

[19] A. Purohit, L. W. L. Woo, A. Singh, C. J. Winterborn, B. V. L. Potter, M. J. Reed, In vivo activity of 4methylcoumarin-7-O-sulfamate, a nonsteroidal, nonestrogenic sulfatase inhibitor, Cancer Res. 56 (1996) 4950-4955.

[20] C. Palmieri, R.C. Stein, X. Liu, E. Hudson, H. Nicholas, H. Sasano, F. Guestini, C. Holcombe, S. Barrett, L. Kenny, IRIS study: a phase II study of the steroid sulfatase inhibitor Irosustat when added to an aromatase inhibitor in ER-positive breast cancer patients, Breast Cancer Res. Treat. 165 (2017) 343-353.

[21] C. Palmieri, R. Szydlo, M. Miller, L. Barker, N.H. Patel, H. Sasano, T. Barwick, H. Tam, D. Hadjiminas, J. Lee, IPET study: an FLT-PET window study to assess the activity of the steroid sulfatase inhibitor irosustat in early breast cancer. Breast Cancer Res. Treat. 166 (2017) 527-539.

[22] P. Nussbaumer, D. Geyl, A. Horvath, P. Lehr, B. Wolff, A. Billich, Nortropinyl-arylsulfonylureas as novel, reversible inhibitors of human steroid sulfatase, Bioorg. Med. Chem. Lett. 13 (2003) 3673-3677.

[23] P. Lehr, A. Billich, B. Wolff, P. Nussbaumer, N-Acyl arylsulfonamides as novel, reversible inhibitors of human steroid sulfatase, Bioorg. Med. Chem. Lett. 15 (2005) 1235-1238.

[24] V. Ahmed Y. Liu S. D. Taylor, Multiple Pathways for the Irreversible Inhibition of Steroid Sulfatase with Quinone Methide-Generating Suicide Inhibitors. Chem. Bio Chem. 10 (2009) 1457-1461.

[25] C. M. Phan, Y Liu, B. M. Kim, Y. Mostafa , S. D. Taylor, Inhibition of steroid sulfatase with 4-substituted estrone and estradiol derivatives, Bioorg. Med. Chem. 19 (2011) 5999-6005.

[26] S. Demkowicz, W. Kozak, M. Daśko, M. Masłyk, B. Gielniewski, J. Rachon, Synthesis of bicoumarin thiophosphate derivatives as steroid sulfatase inhibitors, Eur. J. Med. Chem. 101 (2015) 358-366.

[27] S. Demkowicz, W. Kozak, M. Dasko, A. Wołos, M. Masłyk, K. Kubinski, A. Składanowski, M. Misiak, J. Rachon, Synthesis and steroid sulfatase inhibitory activities of $\mathrm{N}$-alkanoyl tyramine phosphates and 
thiophosphates, RSC Adv. 5 (2015) 32594-32603.

[28] L. W. L. Woo, C. Bubert, A. Purohit, B. V. L. Potter, Hybrid Dual Aromatase-Steroid Sulfatase Inhibitors with Exquisite Picomolar Inhibitory Activity, ACS Med. Chem. Lett. 2 (2011) 243-247.

[29] M. Daśko, J. Rachon, M. Masłyk, K. Kubiński, S. Demkowicz Synthesis and biological evaluation of $N$ acylated tyramine sulfamates containing C-F bonds as steroid sulfatase inhibitors, Chem. Biol. Drug. Des. 90 (2017) 156-161.

[30] L. W. L. Woo et al B. V. L. Potter, Synthesis and structure-activity relationship studies of derivatives of the dual aromatase-sulfatase inhibitor 4-\{[(4-cyanophenyl)(4H-1,2,4-triazol-4-yl)amino]2methyl\}phenyl sulfamate, Chem. Med. Chem. 8 (2013) 779-99.

[31] Li P.-K., S. Milano, L. Kluth, M.E. Rhodes, Synthesis and sulfatase inhibitory activities of non-steroidal estrone sulfatase inhibitors, J. Steroid Biochem. Mol. Biol. 59 (1996) 41-48.

[32] A. Kolli, G.H. Chu, M.E. Rhodes, K. Inoue, K.W. Selcer, P.-K. Li, Development of ( $p$-O-sulfamoyl)-Nalkanoyl-phenylalkyl amines as non-steroidal estrone sulfatase inhibitors, J. Steroid Biochem. Mol. Biol. 68 (1999) 31-40.

[33] M. Okada, T. Nakagawa, S. Iwashita, S. Takegawa, T. Fujii, N. Koizumi, Development of novel steroid sulfatase inhibitors: Synthesis and biological evaluation of biphenyl-4-O-sulfamates, J. Steroid Biochem. Mol. Biol. 87 (2003) 141-148.

[34] M. I. El-Gamal, M. H. Semreen, P. A. Foster, B. V. L. Potter, Design, synthesis, and biological evaluation of new arylamide derivatives possessing sulfonate or sulfamate moieties as steroid sulfatase enzyme inhibitors, Bioorg. Med. Chem. 24 (2016) 2762-2767.

[35] C. Laurence, K.A. Brameld, J. Graton, J.Y. Le Questel, E. Renault, The pKBHX Database: Toward a Better Understanding of Hydrogen-Bond Basicity for Medicinal Chemists, J. Med. Chem. 52 (2009) 4073-4086.

[36] B. Kuhn, J.E. Fuchs, M. Reutlinger, M. Stahl, N.R Taylor, Rationalizing Tight Ligand Binding through Cooperative Interaction Networks, J. Chem. Inf. Model. 51 (2011) 3180-3198.

[37] A. Todorovic, C. Haskell-Luevano, A review of melanocortin receptor small molecule ligands, Peptides, 26 (2005), 2026-2036.

[38] M. Okada, S. Iwashita, N. Koizumi, Efficient General Method for Sulfamoylation of a Hydroxyl Group, Tetrahedron Lett. 41 (2000) 7047-7051.

[39] C. H. Mack, H. H. McGregor, Jr., S. R. Hobart, Synthesis of some phenyl N-arylcarbamates. J. Chem. Eng. Data 14 (1969) 258-261.

[40] D. L. Coffen, M. P. Dillon, A. P. Ford, Z. Li, T. J. Williams, US Patent 2002, 6355641 B1.

[41] C. Congiu, V. Onnis, A. Deplano, G. Balboni, M. Ceruso, C.T. Supuran Synthesis and carbonic anhydrase I, II, IX and XII inhibitory activity of sulfamates incorporating piperazinyl-ureido moieties. Bioorg. Med. Chem. 23 (2015) 5619-5625. 